\title{
Inter-element fractionation of highly siderophile elements in the Tonga Arc due to flux melting of a depleted source
}

\author{
Christopher W. Dale ${ }^{\mathrm{a}, *}$, Colin G. Macpherson ${ }^{\mathrm{a}}$, D. Graham Pearson ${ }^{\mathrm{a}, 1}$, \\ Samantha J. Hammond ${ }^{\mathrm{b}}$, Richard J. Arculus ${ }^{\mathrm{c}}$ \\ a NCIET, Department of Earth Sciences, Durham University, Science Laboratories, Durham DH1 3LE, UK \\ ${ }^{\mathrm{b}}$ Department of Earth and Environmental Sciences, CEPSAR, The Open University, Walton Hall, Milton Keynes MK7 6AA, UK \\ ${ }^{\mathrm{c}}$ Department of Earth \& Marine Sciences, Australian National University, ACT 0200, Australia
}

Received 19 May 2011; accepted in revised form 16 March 2012; available online 27 March 2012

\begin{abstract}
Highly siderophile element concentrations (HSEs: Os, Ir, Ru, Pt, Pd, and Re) have been determined for a suite of fresh, submarine mafic lavas from the northern Tonga Arc front and the nascent backarc Fonualei Spreading Centre (FSC). Prior melt depletion of the Tongan mantle wedge combined with a high degree of fluid fluxed melting is thought to have produced boninitic magmas at several arc and FSC locations. As such, this arc system provides an opportunity to assess the fluid mobility of HSEs and to investigate the effects of fluid-induced melting and prior melt depletion on HSE behaviour during both mantle melting and magma evolution.

Tongan lavas display extreme enrichment of Pt (2.5-32 ng/g) and Pd over Os (0.002-0.6 ng/g), Ir, and Ru, significantly greater than basalts from mid-ocean ridges. Magma evolution increases the degree of fractionation, resulting in the highest recorded $\mathrm{Pt} / \mathrm{Ru}$ ratios $(>300)$ in arc front samples with $\mathrm{MgO}<8 \mathrm{wt} . \%$. This increasing fractionation is due to the mild incompatibility of $\mathrm{Pt}$ and $\mathrm{Pd}$, and concurrent compatibility of $\mathrm{Ru}$, during sulphide undersaturated magma evolution. However, the fractionation of $\mathrm{Pt}$ and $\mathrm{Pd}$ from $\mathrm{Os}$, $\mathrm{Ir}$, and $\mathrm{Ru}$ is observed in the highest $\mathrm{MgO}$ samples, indicating source inheritance. Prior melt depletion of the mantle and elevated oxygen fugacity both increase the likelihood of complete consumption of sulphide in the source during melting, which typically leads to melts with high concentrations of all the HSE. Indeed, modelling indicates that $25 \%$ aggregate partial melting of a depleted MORB-mantle source, proposed for the Tonga Arc, will lead to complete base-metal sulphide consumption unless there is considerable addition of $\mathrm{S}$ by the slab flux (at least $200 \mu \mathrm{g} / \mathrm{g}$ ). Although source enrichment of $\mathrm{Pt}, \mathrm{Pd}$, and Re by slab fluids may take place, the fractionation of $\mathrm{Pt}$ and $\mathrm{Pd}$ from $\mathrm{Os}$, Ir, and $\mathrm{Ru}$ can largely be explained by relatively low-temperature, yet high-degree, melting of fluid-fluxed melt-depleted mantle. The high $\mathrm{Pt}$ and Pd contents can be produced by the exhaustion of sulphide in the source, while the presence of Ru-Os-(Ir) alloys or sulphides (e.g. laurite) associated with Cr-spinel can explain Os, Ir, and Ru retention in the source residue. Such phases have been documented in fluid-fluxed sub-arc mantle from ophiolites.

Osmium isotopes co-vary negatively with Os abundance and thus appear to be dominated by shallow level contamination. The most Os-rich samples, however, have ${ }^{187} \mathrm{Os} /{ }^{188} \mathrm{Os}$ ratios $(0.126-0.132)$ which are typical of DMM and MORB, suggesting an indistinguishable flux of radiogenic Os from the slab. The significant fractionation of Pt and Re from Os in arc settings will lead, over time, to elevated ${ }^{186} \mathrm{Os}$ and ${ }^{187} \mathrm{Os}$ which may be relevant to the observed enrichments of these isotopes in some mantle regions. In addition, the differing behaviour of $\mathrm{Ru}$ and $\mathrm{Ir}$, and the implication of a mantle source containing Ru-rich microphases, may have consequences for the estimation of the HSE composition of primitive upper mantle.
\end{abstract}

(c) 2012 Elsevier Ltd. All rights reserved.

\footnotetext{
* Corresponding author. Tel.: +44 0191 3342357; fax: +44 01913342301.

E-mail address: christopher.dale@durham.ac.uk (C.W. Dale).

${ }^{1}$ Present address: Department for Earth and Atmospheric Sciences, University of Alberta, Edmonton, Alberta, Canada T6G 2 E3.
} 


\section{INTRODUCTION}

Subduction zones form a crucial part of global tectonics, global elemental cycling and long-term differentiation of the solid Earth. While numerous detailed studies have been conducted on the behaviour of lithophile and high-fieldstrength elements in the subduction cycle (e.g. Hawkesworth et al., 1993; Plank and Langmuir, 1993; Pearce and Peate, 1995; Elliott et al., 1997; Hermann et al., 2006; König et al., 2010), relatively little information exists on the highly siderophile elements (HSE: Re, Au and platinum group elements; PGE: Os, Ir, Ru, Rh, Pt, and Pd), despite the occurrence of major alluvial platinum sources in some arc systems (Cabri et al., 1996). The HSEs host two important long-lived radioactive decay systems that are important tracers of mantle evolution (Re-Os and Pt-Os; Shirey and Walker, 1998). It is critical that we understand the influence of subduction zone fractionation processes on these isotopic systems if we are to develop our understanding of how they record mantle and crust evolution. Furthermore, the increasing debate about the source of $\mathrm{Au}$ enrichment in arc settings (e.g. Mungall, 2002; Botcharnikov et al., 2011) and the use of the $\mathrm{Re}-\mathrm{Os}$ isotope system in dating and tracing metal sources in large $\mathrm{Cu}-\mathrm{Au}-\mathrm{Mo}-$ porphyry systems (e.g. McInnes et al., 1999) make it important to increase our understanding of the geochemical behaviour of HSEs relative to other metals in subduction systems.

Thus far, our knowledge of the behaviour of HSEs in subduction zone systems remains rudimentary; from the stability of key phases in the down-going slab (e.g. Dale et al., 2009a), to their mobility in slab fluids and melts (e.g. Wood et al., 1992; Kepezhinskas et al., 2002), and their behaviour during melting of a metasomatised mantle wedge (e.g. Mungall, 2002). Re-Os studies have suggested that Re may be lost preferentially from the basaltic parts of the down-going slab and therefore probably transferred into the mantle wedge (Becker, 2000; Dale et al., 2007). Complementary evidence in the form of high Re concentrations in arc melt inclusions is consistent with this proposal (Sun et al., 2003a). Studies of arc-mantle xenoliths have indicated significant enrichments in $\mathrm{Pt}, \mathrm{Au}$ and, to a lesser extent, Pd (McInnes et al., 1999; Kepezhinskas et al., 2002), possibly indicating a substantial flux of HSEs from the slab, but studies of arc magmas have been inconclusive (Brandon et al., 1996; Woodland et al., 2002; Woodhead and Brauns, 2004; Dreher et al., 2005). Given the importance of sulphide in controlling the budgets of the HSE (e.g. Peach et al., 1990; Rehkämper et al., 1999; Alard et al., 2000; Luguet et al., 2004; Lorand et al., 2008; Harvey et al., 2011) the behaviour of sulphur in subduction zones, and in particular whether sulphide remains in the mantle source, is crucial to our understanding of HSE behaviour. Prior melt depletion (which reduces $S$ content), addition of $S$ to the mantle wedge from the downgoing slab (e.g. de Hoog et al., 2001) and oxygen- and sulphur-fugacity in the mantle source and magma will all have a bearing on sulphur behaviour and, in turn, the behaviour of HSEs (e.g. Mungall et al., 2006; Jugo et al., 2010).

The Tonga Arc system is ideally suited to the study of these processes because it is considered to be a relatively simple end-member arc system, dominated by fluid flux from the mafic slab, rather than sediment or melt input (Turner and Hawkesworth, 1997). The long history of melt depletion (e.g. Ewart and Hawkesworth, 1987; Hawkins, 1995) also provides the opportunity to investigate the effects of previous melt extraction on HSE behaviour during mantle melting. In places along the arc system, $\mathrm{Si}-$ and $\mathrm{Mg}$-rich boninitic magmas - a very rare present-day example of boninitic volcanism on Earth (Cooper et al., 2010) - have been produced by melting of a highly-depleted, fluid-fluxed manthe source (Crawford et al., 1989). Here we report concentrations of highly siderophile elements (Os, Ir, Ru, Pt, Pd, and $\mathrm{Re}$ ) for boninitic, basaltic and basaltic andesite lavas from the central and northern sections of the Tonga Arc, the Fonualei Spreading Centre (FSC), and the Mangatolu Triple Junction (MTJ). We find that the fractionation of $\mathrm{Pt}$ and Pd (palladium-group PGE: PPGE) from Os, Ir, and $\mathrm{Ru}$ (iridium-group: IPGE) is amongst the greatest documented in terrestrial melts. We postulate that this fractionation is largely dependent on (1) the exhaustion of sulphide in the mantle source, which is dependent on the degree of both partial melting and prior melt depletion and the redox conditions of the mantle, and (2) the retention of IPGE in the mantle residue by platinum-group minerals and $\mathrm{Cr}$-spinel. The dominant influence of these processes makes it difficult to identify $\mathrm{Pt}, \mathrm{Pd}$, and $\mathrm{Re}$ enrichment accompanying a slab flux (Dale et al., 2009a), though it is likely that this does contribute to the observed enrichment.

\section{GEOLOGICAL SETTING OF THE TONGA ARC, SAMPLING AND PETROLOGY}

The Tonga Arc forms the northern part of the intra-oceanic Tonga-Kermadec subduction zone which stretches $2800 \mathrm{~km}$ from the North Island of New Zealand, in the south, to the island of Tafahi in the north. The Tongan part of this arc is characterised by severe depletion of the mantle wedge due to a long history of melting (Hawkins, 1995) including that associated with production of new sea floor during opening of the Lau Basin. The degree of depletion in the Tonga Arc mantle makes the system a particularly sensitive natural laboratory to investigate recycling of elements by fluids and/ or melts from the subducting slab. Slab surface temperatures of the subducted Pacific Plate should be relatively low due to its relative antiquity (approximately $100 \mathrm{Ma}$ ), fast subduction (up to $240 \mathrm{~mm} \mathrm{a}^{-1}$ in the north) and steady-state long lived subduction (since at least the upper Eocene; Ewart and Bryan, 1972). Consequently, the flux from the slab is likely to be dominated by fluid, rather than melt. However, recent work by Plank et al. (2009) suggests that even in this subduction zone, slab fluids may be $>700{ }^{\circ} \mathrm{C}$ and therefore not aqueous fluids but solute-rich fluids or melts. The central part of the Tonga Arc is dominated by a flux from the mafic slab as there is little sediment thickness on the western Pacific oceanic plate (70-100 m of pelagic sediment; Regelous et al., 2010 and references therein). Northern arc- and some Lau Basin lavas possess a signature of the Samoan hotspot mantle (Poreda and Craig, 1992) and subducted sediments similar to those sampled at DSDP Site 204 and ODP Site 596 (Turner and Hawkesworth, 1997; Regelous et al., 2008, 2010). 
Backarc spreading is largely accommodated on the Central and Eastern Lau spreading centres, terminating in the Valu-Fa rift to the south and several minor spreading centres in the north (e.g. the northern and north-west spreading centres). However, recent rifting close to the northern arc front has produced the Fonualei Spreading Centre, stretching from close to the island of Fonualei to the ridge-ridge-ridge Mangatolu Triple Junction in the north (Fig. 1). A detailed summary of the geological setting of the Tonga-Kermadec Arc, Lau Basin and Fonualei Spreading Centre can be found in Keller et al. (2008).

The samples in this study were dredged from submarine volcanoes in the central and northern parts of the Tonga (Tofua) Arc (from Tongatapu northwards), the nascent Fonualei Spreading Centre and the Mangatolu Triple Junc- tion (Fig. 1), during the NoToVE voyage in 2004. Although the central and northern part of the Tonga Arc consists of only approximately 10 subaerial volcanoes, there are numerous submarine volcanic edifices. During the sampling voyage, bathymetry and acoustic backscatter swath mapping, using multi-beam sonar, were used to identify more than 10 such submarine volcanoes, and target young, fresh volcanic features for dredging operations.

Most of the samples recovered were glassy phyric basalts and basaltic andesites, variously containing olivine, pyroxene or plagioclase phenocrysts, commonly with glassy crusts of a few millimetres thick. Spinel is also common, but sulphide was not found in any of the thin sections investigated. Glass crusts and pillow cores (commonly containing some glass as well as phenocrysts) were analysed in

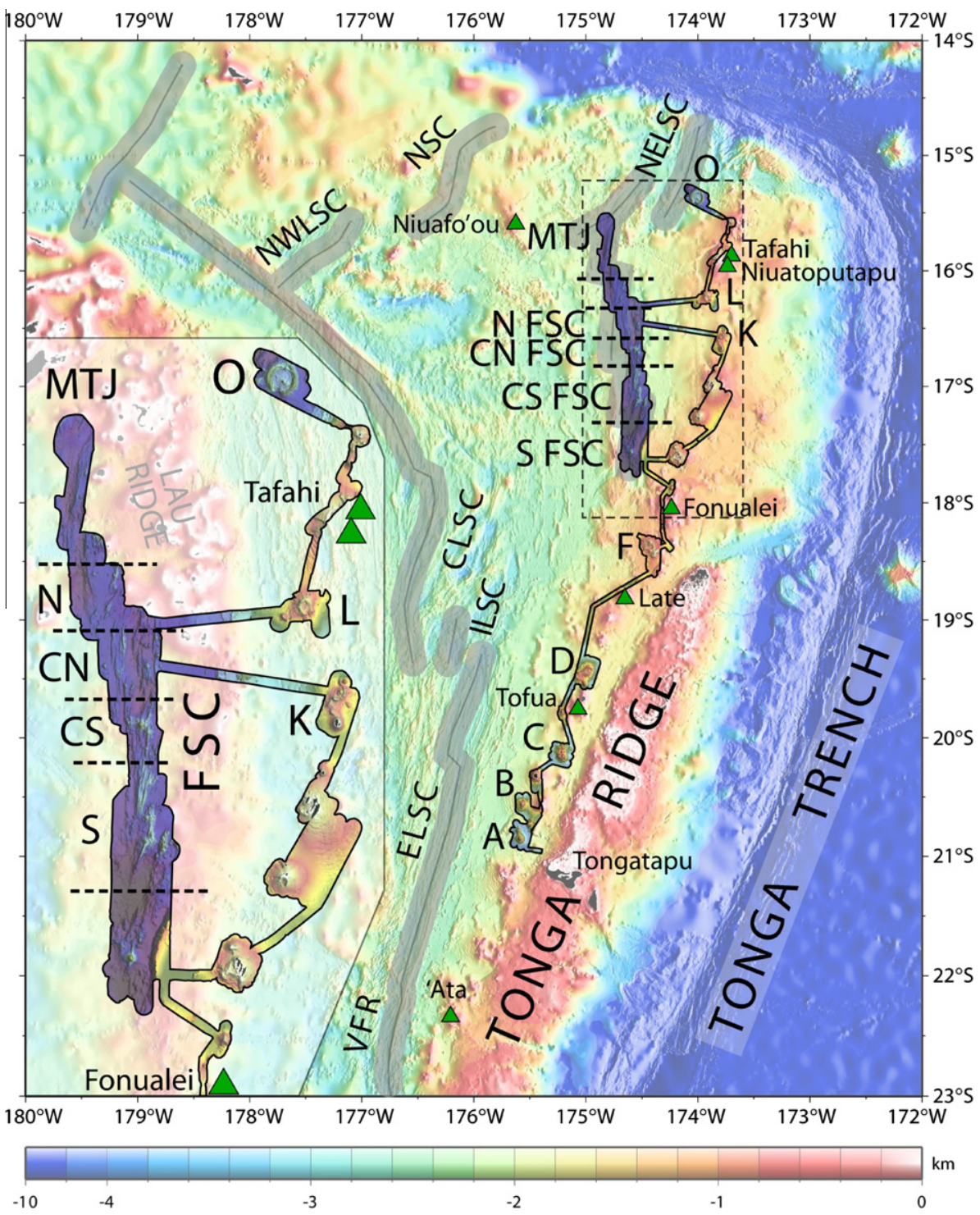

Fig. 1. Map of the Tonga-Lau system (after Zellmer and Taylor, 2001), and detail of the swath mapping undertaken on NoToVE voyage and locations dredged. Depth scale corresponds to regional map, not swath mapping. Inset: detail of the northern, central-northern, centralsouthern and southern Fonualei Spreading Centre (FSC) and northern arc section. MTJ - Mangatolu Triple Junction; VFR - Valu Fa Ridge; ELSC, ILSC and CLSC - East, Intermediate and Central Lau Spreading Centres; NSC, NWLSC and NELSC - North, Northwest, Northeast Lau Spreading Centres. (For interpretation to colours in this figure, the reader is referred to the web version of this paper.) 
Table 1

Highly siderophile element (HSE) concentrations, Os isotopes and selected major and trace element data for submarine mafic lavas from the Tonga Arc, Fonualei Spreading Centre and Mangatolu Triple Junction.

\begin{tabular}{|c|c|c|c|c|c|c|c|c|c|c|c|c|c|c|c|c|c|c|c|}
\hline Sample \& location & & Lat.(S) & Long.(W) & $\begin{array}{l}\mathrm{MgO} \\
\text { (wt.\%) }\end{array}$ & $\begin{array}{l}\mathrm{Cr} \\
\text { (ug/g) }\end{array}$ & $\begin{array}{l}\mathrm{Ni} \\
\text { (ug/g) }\end{array}$ & $\begin{array}{l}\mathrm{Cu} \\
(\mathrm{ug} / \mathrm{g})\end{array}$ & $\begin{array}{l}S \\
\text { (ug/g) }\end{array}$ & $\mathrm{Ba} / \mathrm{La}$ & $\mathrm{Th} / \mathrm{Yb}$ & $\mathrm{Nb} / \mathrm{Yb}$ & ${ }^{187} \mathrm{Os} /{ }^{188} \mathrm{Os}$ & $\begin{array}{l}{ }^{187} \mathrm{Re} / \\
{ }^{188} \mathrm{Os}\end{array}$ & $\begin{array}{l}\text { Os } \\
(\mathrm{ng} / \mathrm{g})\end{array}$ & $\begin{array}{l}\mathrm{Ir} \\
(\mathrm{ng} / \mathrm{g})\end{array}$ & $\begin{array}{l}\mathrm{Ru} \\
(\mathrm{ng} / \mathrm{g})\end{array}$ & $\begin{array}{l}\mathrm{Pt} \\
(\mathrm{ng} / \mathrm{g})\end{array}$ & $\begin{array}{l}\mathrm{Pd} \\
(\mathrm{ng} / \mathrm{g})\end{array}$ & $\begin{array}{l}\mathrm{Re} \\
(\mathrm{ng} / \mathrm{g})\end{array}$ \\
\hline \multicolumn{20}{|l|}{ Tonga Arc } \\
\hline \multicolumn{20}{|l|}{ Central arc } \\
\hline ND-02-01 & A & $20^{\circ} 48$ & $175^{\circ} 33$ & 8.05 & 257 & 64 & 108 & - & 159 & 0.050 & 0.09 & $0.1787 \pm 0.0003$ & 267 & 0.006 & 0.052 & 0.023 & 7.91 & 10.7 & 0.339 \\
\hline ND-03-01 (WR) & A & & & 14.0 & 702 & 148 & 91 & - & 178 & 0.051 & 0.09 & $0.1332 \pm 0.0001$ & 40.4 & 0.048 & 0.130 & 0.137 & 21.0 & 21.2 & 0.398 \\
\hline $\mathrm{ND}-03-01(\mathrm{G})$ & A & $20^{\circ} 50$ & $175^{\circ} 33$ & & & & & & & & & $0.1342 \pm 0.0002$ & 114 & 0.018 & 0.042 & 0.069 & 9.30 & 17.1 & 0.417 \\
\hline ND-04-01 & A & $20^{\circ} 44.5$ & $175^{\circ} 34$ & 10.1 & 448 & 132 & 87 & - & 124 & 0.062 & 0.10 & $0.1399 \pm 0.0002$ & 111 & 0.020 & 0.142 & 0.107 & 8.41 & 14.3 & 0.450 \\
\hline repl. & & & & & & & & & & & & $0.1557 \pm 0.0003$ & 103 & 0.021 & 0.148 & 0.108 & 9.24 & 15.0 & 0.457 \\
\hline repl. & & & & & & & & & & & & $0.1311 \pm 0.0001$ & 30 & 0.078 & 0.150 & - & 5.95 & 26.1 & 0.479 \\
\hline repl. \# & & & & & & & & & & & & $0.1368 \pm 0.0003$ & 81 & 0.028 & 0.149 & 0.112 & 8.24 & 13.4 & 0.476 \\
\hline ND-08-01 & B & $20^{\circ} 36$ & $175^{\circ} 31$ & 5.86 & 53 & 35 & 110 & - & 25.6 & 0.121 & 0.20 & $0.2113 \pm 0.0007$ & 681 & 0.002 & 0.044 & 0.008 & 9.71 & 11.4 & 0.325 \\
\hline ND-23-01 & $\mathrm{D}$ & $19^{\circ} 29$ & $174^{\circ} 57$ & 5.42 & 27 & 17 & 104 & - & 60.6 & 0.093 & 0.14 & $0.2001 \pm 0.0004$ & 1514 & 0.003 & 0.105 & 0.006 & 2.47 & 0.671 & 1.03 \\
\hline ND-29-01 & $\mathrm{F}$ & $18^{\circ} 20$ & $174^{\circ} 24$ & 3.79 & 27 & 17 & 104 & - & 65.4 & 0.082 & 0.15 & $0.3371 \pm 0.0006$ & - & 0.002 & - & - & - & - & - \\
\hline \multicolumn{20}{|l|}{ Northern arc } \\
\hline ND-54-01 & $\mathrm{K}$ & $16^{\circ} 32$ & $173^{\circ} 45$ & 4.20 & 6.5 & 5.6 & 155 & - & 64.7 & 0.085 & 0.28 & $0.41 \pm 0.06$ & 433 & 0.001 & 0.001 & 0.005 & 0.152 & 4.05 & 0.072 \\
\hline ND-71-01 & $\mathrm{L}$ & $16^{\circ} 14$ & $173^{\circ} 56$ & 10.2 & 402 & 156 & 124 & - & 37.5 & 0.427 & 0.97 & $0.1363 \pm 0.0001$ & 74.2 & 0.028 & 0.097 & 0.077 & 9.02 & 15.1 & 0.426 \\
\hline ND-73-01 (G) & $\mathrm{O}$ & $15^{\circ} 22$ & $174^{\circ} 00$ & 1.64 & 2.6 & 3.5 & 127 & - & 24.7 & 0.787 & 2.93 & $0.1784 \pm 0.0005$ & 1763 & 0.004 & 0.005 & 0.004 & 1.35 & 1.62 & 1.61 \\
\hline ND-74-01 & $\mathrm{O}$ & $15^{\circ} 17$ & $174^{\circ} 05$ & 9.91 & 436 & 120 & 94 & - & 23.7 & 0.631 & 3.22 & $0.1385 \pm 0.0001$ & 67.5 & 0.032 & 0.048 & 0.338 & 9.68 & 20.6 & 0.447 \\
\hline \multicolumn{20}{|c|}{ Fonualei Spreading Centre } \\
\hline ND-46-01 & $\mathrm{S}$ & $17^{\circ} 32$ & $174^{\circ} 34$ & 6.27 & 34 & 41 & 100 & 67 & 36.7 & 0.142 & 0.35 & $1.4232 \pm 0.0003$ & 1142 & 0.005 & 0.010 & 0.029 & 5.08 & 8.21 & 1.04 \\
\hline ND-47-01 & $\mathrm{S}$ & $17^{\circ} 37$ & $174^{\circ} 34$ & 13.3 & 781 & 352 & 82 & 120 & 33.0 & 0.150 & 0.32 & $0.1543 \pm 0.0001$ & 135 & 0.031 & 0.201 & 0.220 & 4.36 & 4.13 & 0.855 \\
\hline repl. \# & & & & & & & & & & & & $0.1518 \pm 0.0001$ & 122 & 0.035 & 0.197 & 0.188 & 4.09 & 4.05 & 0.873 \\
\hline \multicolumn{20}{|l|}{ Southern Central } \\
\hline ND-37-01 & CS & $17^{\circ} 01$ & $174^{\circ} 30$ & 8.64 & 324 & 94 & 105 & 145 & 18.4 & 0.106 & 0.22 & $0.1458 \pm 0.0001$ & 243 & 0.012 & 0.249 & 0.045 & 5.98 & 9.17 & 0.581 \\
\hline ND-38-01 \# & $\mathrm{CS}$ & $17^{\circ} 04$ & $174^{\circ} 34$ & 13.8 & 786 & 345 & 80 & 121 & 27.8 & 0.164 & 0.32 & $0.1317 \pm 0.0001$ & 14.7 & 0.295 & 0.509 & 0.331 & 31.7 & 60.6 & 0.901 \\
\hline ND-39-01 & $\mathrm{CS}$ & $17^{\circ} 05$ & $174^{\circ} 32$ & 6.99 & 69 & 57 & 116 & 89 & 27.3 & 0.118 & 0.29 & $0.1755 \pm 0.0003$ & 751 & 0.006 & 0.021 & 0.040 & 7.95 & 16.5 & 0.960 \\
\hline ND-42-01 & $\mathrm{CS}$ & $17^{\circ} 07$ & $174^{\circ} 27$ & 10.6 & 507 & 206 & 78 & 39 & 29.4 & 0.129 & 0.26 & $0.1346 \pm 0.0001$ & 86.5 & 0.030 & 0.102 & 0.215 & 2.97 & 4.23 & 0.547 \\
\hline repl. \# & & & & & & & & & & & & $0.1320 \pm 0.0001$ & 80.7 & 0.034 & 0.119 & 0.183 & 2.48 & 3.25 & 0.565 \\
\hline \multicolumn{20}{|l|}{ Northern Central } \\
\hline ND-60-01 (WR) & & & & 7.49 & 225 & 87 & 113 & - & 29.6 & 0.176 & 0.45 & $0.2135 \pm 0.0007$ & 1355 & 0.002 & 0.015 & - & 6.27 & 13.6 & 0.770 \\
\hline ND-60-01 (G) & $\mathrm{CN}$ & $16^{\circ} 45$ & $174^{\circ} 31$ & 6.21 & 84 & 59 & 130 & 47 & 29.6 & 0.171 & 0.41 & $0.5293 \pm 0.0007$ & 1921 & 0.003 & 0.013 & 0.032 & 6.22 & 14.0 & 0.808 \\
\hline ND-61-01 & $\mathrm{CN}$ & $16^{\circ} 40$ & $174^{\circ} 31$ & 9.89 & 412 & 160 & 94 & 28 & 33.9 & 0.181 & 0.42 & $0.1329 \pm 0.0001$ & 79.4 & 0.035 & 0.095 & 0.160 & 9.10 & 15.8 & 0.580 \\
\hline ND-62-01 \# & $\mathrm{CN}$ & $16^{\circ} 40$ & $174^{\circ} 32$ & 6.85 & 130 & 59 & 113 & 31 & 28.9 & 0.223 & 0.51 & $0.2096 \pm 0.0003$ & 640 & 0.005 & 0.050 & 0.082 & 6.36 & 12.0 & 0.709 \\
\hline \multicolumn{19}{|l|}{ Northern } & 1.08 \\
\hline ND-66-01 \# & $\mathrm{N}$ & $16^{\circ} 28$ & $174^{\circ} 37$ & 7.43 & 198 & 70 & 105 & 159 & 31.6 & 0.177 & 0.67 & $0.1351 \pm 0.0001$ & 131 & 0.028 & 0.104 & 0.223 & 4.55 & 15.6 & 0.755 \\
\hline ND-68-01 & $\mathrm{N}$ & $16^{\circ} 27$ & $174^{\circ} 31$ & 12.4 & 577 & 253 & 84 & 76 & 27.6 & 0.231 & 0.61 & $0.1393 \pm 0.0001$ & 31.6 & 0.094 & 0.181 & 0.373 & 9.48 & 11.8 & 0.613 \\
\hline
\end{tabular}




\begin{tabular}{|c|c|c|c|c|c|c|c|c|c|c|c|c|c|c|c|c|c|c|}
\hline Sample \& location & Lat.(S) & Long.(W) & $\begin{array}{l}\mathrm{MgO} \\
\text { (wt.\%) }\end{array}$ & $\begin{array}{l}\mathrm{Cr} \\
\text { (ug/g) }\end{array}$ & $\begin{array}{l}\mathrm{Ni} \\
\text { (ug/g) }\end{array}$ & $\begin{array}{l}\mathrm{Cu} \\
\text { (ug/g) }\end{array}$ & $\begin{array}{l}\mathrm{S} \\
\text { (ug/g) }\end{array}$ & $\mathrm{Ba} / \mathrm{La}$ & $\mathrm{Th} / \mathrm{Yb}$ & $\mathrm{Nb} / \mathrm{Yb}$ & ${ }^{187} \mathrm{Os} /{ }^{188} \mathrm{Os}$ & $\begin{array}{l}{ }^{187} \mathrm{Re} / \\
{ }^{188} \mathrm{Os}\end{array}$ & $\begin{array}{l}\mathrm{Os} \\
(\mathrm{ng} / \mathrm{g})\end{array}$ & $\begin{array}{l}\mathrm{Ir} \\
(\mathrm{ng} / \mathrm{g})\end{array}$ & $\begin{array}{l}\mathrm{Ru} \\
(\mathrm{ng} / \mathrm{g})\end{array}$ & $\begin{array}{l}\mathrm{Pt} \\
(\mathrm{ng} / \mathrm{g})\end{array}$ & $\begin{array}{l}\mathrm{Pd} \\
(\mathrm{ng} / \mathrm{g})\end{array}$ & $\begin{array}{l}\operatorname{Re} \\
(\mathrm{ng} / \mathrm{g})\end{array}$ \\
\hline \multicolumn{19}{|l|}{ Mangatolu Triple Junction } \\
\hline ND-69-01 & $15^{\circ} 36$ & $174^{\circ} 49$ & 7.07 & 222 & 81 & 75 & 922 & 11.8 & 0.127 & 12.5 & $0.1557 \pm 0.0002$ & 449 & 0.007 & 0.012 & 0.021 & 0.174 & 0.748 & 0.686 \\
\hline repl. (no HF) & & & & & & & & & & & $0.1666 \pm 0.0010$ & - & 0.008 & 0.012 & - & 0.155 & - & - \\
\hline ND-70-01 & $15^{\circ} 51$ & $174^{\circ} 50$ & 8.84 & 348 & 100 & 81 & - & 11.3 & 0.130 & 11.0 & $0.2073 \pm 0.0004$ & 321 & 0.008 & 0.075 & 0.012 & 0.273 & 0.104 & 0.538 \\
\hline repl. (no HF) & & & & & & & & & & & $0.2017 \pm 0.0003$ & - & 0.008 & 0.071 & 0.017 & 0.251 & 0.113 & - \\
\hline ND-70-01 (G) (no HF) & & & & & & & 889 & & & & $0.1475 \pm 0.0005$ & & 0.004 & 0.007 & 0.011 & 0.175 & 0.075 & - \\
\hline \multicolumn{19}{|l|}{ Reference materials } \\
\hline TDB-1 & & & & & & & & & & & $0.9359 \pm 0.0009$ & 36.3 & 0.120 & 0.063 & 0.195 & 4.92 & 22.5 & 0.820 \\
\hline repl. & & & & & & & & & & & $0.9688 \pm 0.0003$ & 41.5 & 0.104 & 0.059 & 0.188 & 4.63 & 24.7 & 0.809 \\
\hline repl. & & & & & & & & & & & $0.9076 \pm 0.0003$ & 39.8 & 0.117 & 0.067 & 0.206 & 4.89 & 24.5 & 0.875 \\
\hline repl. & Desilicified & & & & & & & & & & - & - & - & 0.061 & 0.251 & 5.82 & 21.9 & 0.978 \\
\hline repl. & Desilicified & & & & & & & & & & $1.0633 \pm 0.0002$ & 53.9 & 0.100 & 0.050 & 0.221 & 3.86 & 18.9 & 1.00 \\
\hline repl. & Post Os desilicification & & & & & & & & & & $0.9733 \pm 0.0004$ & 55.2 & 0.103 & 0.059 & 0.296 & 4.65 & 22.4 & 1.07 \\
\hline repl. & Post Os desilicification & & & & & & & & & & $1.0531 \pm 0.0003$ & 57.8 & 0.094 & 0.056 & 0.258 & 4.43 & 21.5 & 1.00 \\
\hline Mean ${ }^{*}$ & & & & & & & & & & & $0.973 \pm 0.128$ & - & 0.106 & 0.059 & 0.231 & 4.74 & 22.3 & $1.01^{*}$ \\
\hline $2 \mathrm{RSD}$ & & & & & & & & & & & $13 \%$ & & $19 \%$ & $19 \%$ & $34 \%$ & $25 \%$ & $17 \%$ & $7 \%$ \\
\hline Mulhouse (mean) & & & & & & & & & & & $0.916 \pm 0.195$ & - & 0.117 & 0.075 & 0.198 & 5.01 & 24.3 & 0.794 \\
\hline WHOI (mean) & & & & & & & & & & & - & - & 0.122 & 0.078 & - & 4.4 & 24.8 & - \\
\hline
\end{tabular}

Notes: Samples are glassy whole rock unless denoted 'G' -glass. Samples were desilicified (treated with HF) after aqua regia HPA digestion except: '\#' - HF dissolution was prior to HPA digestion; 'no HF' - no desilicification was performed (only applies to Mangatolu Triple Junction due to incomplete PGE extraction without HF from other samples). Full PGE data without HF digestion for all other samples is shown in Table S1. External uncertainties for HSE concentrations can be estimated from the standard deviation on replicate analyses of TDB-1. However, reproducibility for HSE ratios is significantly better (5-15\%) suggesting a 'nugget effect' rather than an analytical issue with concentration measurements.

Major and trace elements in italics are for glasses from the same samples published by Keller et al. (2008).

Reference materials - TDB-1 values in italics published previously in Dale et al. (2009a), together with values for DR26 type1 and EN026 10D-3.

* Mean value for Re calculated only from desilicified analyses. 
this study. Glass chips from the crusts were picked without surficial phenocrysts but were not necessarily phenocrystfree.

\section{ANALYTICAL METHODS}

The HSE chemistry employed the following basic protocol (Dale et al., 2009a), with the addition of an HF dissolution step (see below) to ensure complete HSE extraction: approximately $1.5 \mathrm{~g}$ of each whole rock powder or powdered glass was digested and equilibrated with a mixed ${ }^{190} \mathrm{Os}-{ }^{185} \mathrm{Re}-{ }^{191} \mathrm{Ir}-{ }^{99} \mathrm{Ru}-{ }^{194} \mathrm{Pt}-{ }^{106} \mathrm{Pd}$-enriched spike, using inverse aqua regia $\left(2.5 \mathrm{~mL} 12 \mathrm{~mol} \mathrm{~L}^{-1} \mathrm{HCl}\right.$ and $5 \mathrm{~mL}$ $16 \mathrm{~mol} \mathrm{~L}^{-1} \mathrm{HNO}_{3}$ ) in a quartz high-pressure asher (HPA) vessel. Vessels were placed in an Anton-Paar HPA at Durham University at $300{ }^{\circ} \mathrm{C}$ for at least $12 \mathrm{~h}$. Osmium was extracted using $\mathrm{CCl}_{4}$, back-extracted into $\mathrm{HBr}$, and then microdistilled (Cohen and Waters, 1996; Birck et al., 1997). The inverse aqua regia was dried and prepared for purification of $\mathrm{Re}$, Ir, Pt, Ru, and Pd using AG1X-8 (100-200\#) anion-exchange resin (after Pearson and Woodland, 2000). Due to the isobaric interference of $\mathrm{ZrO}^{+}$on $\mathrm{Pd}^{+}$, the solvent $N$-benzoyl- $N$-phenyl-hydroxylamine was mixed with and removed from the final sample solutions in order to extract any remaining $\mathrm{Zr}$ after column separation (Shinotsuka and Suzuki, 2007). A further modification to the previous protocol was the addition of $\mathrm{H}_{2} \mathrm{O}_{2}$ during preparation for anion-exchange separation in order to reduce any $\mathrm{Cr}^{6+}$ formed during digestion. This step leads to more efficient $\mathrm{Cr}$ elution prior to HSE collection during chromatographic separation, and consequently reduces potential isobaric interferences of multi-oxide $\mathrm{Cr}$ species with $\mathrm{Ru}$ isotopes during mass spectrometry.

In order to assess the efficacy of HSE extraction from magmatic rocks during aqua regia digestion, a test was performed with an additional HF digestion step. Desilicification was initially performed prior to aqua regia digestion by addition of $6 \mathrm{~mL} 29 \mathrm{~mol} \mathrm{~L}^{-1} \mathrm{HF}$ and $2 \mathrm{~mL} 12 \mathrm{~mol} \mathrm{~L}^{-1}$ $\mathrm{HCl}$ to the sample powder in a Teflon vial, followed by drying and redissolution in $12 \mathrm{~mol} \mathrm{~L}^{-1} \mathrm{HCl}$ at least 3 times (in an unsuccessful attempt to remove all residual fluorides). The residue was then transferred into an HPA vessel and the procedure followed that given above (except digestion was at $240{ }^{\circ} \mathrm{C}$ ). As there was no resolvable increase in Os concentration (Table S1), the addition of HF was subsequently performed after aqua regia digestion and Os extraction, but prior to chromatographic HSE separation (after Pearson and Woodland, 2000). This was preferred in order to eliminate the formation of $\mathrm{HF}$ from residual fluorides during aqua regia reaction and the consequent deleterious effects on the quartz HPA vessels. Concentrations of Re, $\mathrm{Pt}$, and $\mathrm{Pd}$ for digestions without $\mathrm{HF}$ dissolution (Table S1) are typically much lower than those using HF, indicating that these elements are only partially extracted from the sample without desilicification. For some samples, Re yields without $\mathrm{HF}$ are less than $10 \%$ of the total yield when using $\mathrm{HF}$, while average $\mathrm{Pd}$ and $\mathrm{Pt}$ yields are only 40-50\%. Iridium extraction efficiencies for non-HF-digested analyses are typically less than $100 \%$ (of the value when using HF) but vary between $27 \%$ and $200 \%$, with the variability not totally resolvable from sample powder heterogeneity. Ruthenium extraction is less reliant on HF than Ir, with an average efficiency of 105 and $75 \%$ for arc and FSC samples, respectively. Unlike the arc and FSC lavas, extraction of PGE (but not Re) from the MTJ samples is largely independent of the use of HF (Table S1; see Discussion). Following these results, combined HF-aqua regia dissolution was used for all reported analyses of $\mathrm{Ir}, \mathrm{Ru}, \mathrm{Pt}$, $\mathrm{Pd}$, and Re, except for those from the MTJ.

Mass spectrometry procedures for the HSEs are given in Dale et al. (2008). Os was loaded onto Pt filaments and measured as $\mathrm{OsO}_{3}{ }^{-}$ions by negative-thermal ionisation mass spectrometry (N-TIMS) using the ThermoFinnigan ${ }^{\circledR}$ Triton at Durham University. Raw data were corrected offline for $\mathrm{O}$ isotope interference, mass fractionation (using ${ }^{192} \mathrm{Os} /{ }^{188} \mathrm{Os}=3.08271$ ) and spike unmixing. Interference from ${ }^{187} \mathrm{ReO}_{3}{ }^{-}$was insignificant $(\leqslant 2 \mathrm{cps})$. Analyses of 1 and $10 \mathrm{pg}$ aliquots of the Durham Romil Os standard solution (DROsS) gave a mean ${ }^{187} \mathrm{Os} /{ }^{188} \mathrm{Os}$ of $0.16106 \pm$ $0.00138(\sim 0.8 \% 2 \mathrm{RSD}, n=19)$ for the period of analysis, December 2008 - January 2011. These values are in good agreement with a value of $0.160924 \pm 4$ for $10-100 \mathrm{ng} / \mathrm{g}$ aliquots measured on the same mass spectrometer in Faraday cup mode (Luguet et al., 2008a). Rhenium, Ir, Ru, Pt, and $\mathrm{Pd}$ were analysed by inductively-coupled plasma mass spectrometry (ICP-MS) on a ThermoFinnigan ${ }^{\circledR}$ Element 2. Standard HSE, Hf, Zr, Y, and Mo solutions (all $1 \mathrm{ppb}$ ) were analysed at the start, middle and end of each session to quantify the degree of mass fractionation and the production rates of $\mathrm{HfO}^{+}, \mathrm{ZrO}^{+}, \mathrm{YO}^{+}$, and $\mathrm{MoO}^{+}(<0.6$, $<1.5,<0.8,<0.2 \%$, respectively), which have equivalent masses to isotopes of $\mathrm{Ir}^{+}, \mathrm{Pt}^{+}$, and $\mathrm{Pd}^{+}$.

Digestions by HPA gave mean total procedural blanks ( $n=10,2 \mathrm{SD}$ in parentheses) of $0.27 \mathrm{pg}$ Os $(0.4), 0.25 \mathrm{pg}$ Ir (0.2), 10 pg Ru (9), 23 pg Pt (61), typically 9 pg Pd (12) but $\sim 1000 \mathrm{pg}$ Pd for two batches, $1.2 \mathrm{pg} \operatorname{Re}(1.3)$, respectively, and ${ }^{187} \mathrm{Os} /{ }^{188} \mathrm{Os}$ of $0.25(0.1)$. Blank contributions were typically: (with highest blank contribution in brackets) $<10 \%(20 \%),<1 \%(12 \%), 5-30 \%(50 \%),<0.2 \%(2 \%),<0.2 \%$ $(8 \%),<0.2 \%(0.5 \%)$ for Os, Ir, Ru, Pt, Pd, and Re, respectively. Blank corrections relate to the appropriate reagent batch rather than a long-term mean.

Reproducibility and accuracy Replicate digestions of the CANMET doleritic reference material TDB-1 indicate reproducibility of $13 \%$ for ${ }^{187} \mathrm{Os} /{ }^{188} \mathrm{Os}$ ( $2 \mathrm{RSD}, n=7$, Table 1 ), and $7 \%$ for Re concentration, $17-25 \%$ for Os, Ir, $\mathrm{Pt}$, and $\mathrm{Pd}$ and $34 \%$ for $\mathrm{Ru}$. The average values are in good agreement with published data for TDB-1 (Meisel and Moser, 2004, and references therein), suggesting that incomplete digestion and/or sample-spike equilibration is unlikely to be a significant consideration. Replicate analyses of ND-04-01 (Volcano A), and other Tongan lavas, reveal reproducibility of the order: 4-6\% for $\mathrm{Ir}, \mathrm{Ru}$ and $\mathrm{Re}$ ( $n=3-4$ ), $35 \%$ and $69 \%$ for $\mathrm{Pt}$ and $\mathrm{Pd}$, and $41 \%$ and $5 \%$ for low abundance Os concentrations and $\mathrm{Pt} / \mathrm{Ru}$ ratios in three of the four replicates.

Major elements were determined by standard XRF procedures, using an ARL 8400 instrument at the Open University, following procedures outlined in Dale (2005). Uncertainties from multiple analyses of in-house and 
international reference materials are estimated to be better than $2 \%$. Trace element analysis was performed on an Agilent 7500s ICP-MS at the Open University, following dissolution of $0.1 \mathrm{~g}$ of each whole-rock powder with $\mathrm{HF}$ and $\mathrm{HNO}_{3}$, and final dilution to $100 \mathrm{~mL}$ of $2 \% \mathrm{HNO}_{3}$, following methods outlined in detail by Rogers et al. (2006).

\section{MAJOR AND TRACE ELEMENT CHARACTERISATION}

\subsection{Mangotolu Triple Junction (MTJ)}

The lavas from the Mangatolu Triple Junction are largely like mid-ocean ridge basalts (MORB) in their chemistry, and are close to 'typical' backarc basin basalts (BABB). However, MTJ samples are less depleted in light-rare-Earth elements (LREE) $\left(\mathrm{La}_{\mathrm{N}} / \mathrm{Sm}_{\mathrm{N}}\right.$ 0.67-0.8, Keller et al., 2008) than most MORB and Lau Spreading Centre magmas (cf. Sun et al., 2003b). MTJ lavas are more Na-, Ti- and Fe-rich than FSC samples, but contain less K (Sun et al., 2003b; Keller et al., 2008). In terms of mobile and conservative trace elements, the MTJ samples possess a distinct subduction signature with somewhat elevated large-ion lithophile element (LILE)/LREE and LILE/HFSE (high fieldstrength element) ratios (e.g. $\mathrm{Ba} / \mathrm{La}, \mathrm{U} / \mathrm{Nb}$ ) with respect to MORB (Fig. 2). This subduction signature, however, is significantly weaker than in the arc or FSC. As the slab flux is likely to decrease as slab depth increases, due to slab dehydration at shallower levels, the weaker subduction signature is consistent with a greater depth-to-the-slab at the

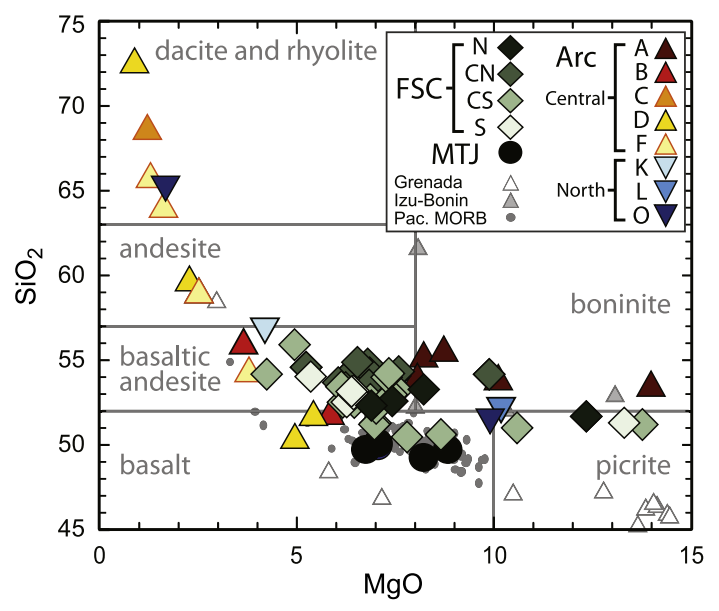

Fig. 2. Ba/La vs. Th/Yb for lavas from the Tonga Arc, Fonualei Spreading Centre and Mangatolu Triple Junction. High Ba/La, relative to MORB, indicates a 'fluid' transfer from the subducting slab, high $\mathrm{Th} / \mathrm{Yb}$ reflects sedimentary input into the mantle wedge. The Tonga Arc is an end-member arc, dominated in its central parts by a fluid flux from the subducting slab, overprinting an already highly-depleted mantle wedge. The northern volcanoes contain a minor sedimentary component and less extreme fluid flux, in part due to the less depleted nature of the mantle wedge in the far north. A subduction fluid contribution to the FSC samples is also evident. MORB compilation from PETDB. Global arc range from Woodhead et al. (2001). (For interpretation to colours in this figure, the reader is referred to the web version of this paper.) point of melt generation in the MTJ region $(\sim 210 \mathrm{~km}$, FSC: 130-180 km, Keller et al., 2008).

\subsection{Fonualei Spreading Centre (FSC)}

$\mathrm{MgO}-\mathrm{SiO}_{2}$ systematics reveal relatively high $\mathrm{SiO}_{2}$ for a given $\mathrm{MgO}$ content in all FSC lavas, compared to MORB, giving these lavas a degree of boninitic affinity (Fig. 2). Boninites are $\mathrm{Si}$ - and $\mathrm{Mg}$-rich arc rocks generated by melting of highly-depleted, fluid-metasomatised mantle (Crawford et al., 1989). Keller et al. (2008) includes a thorough characterisation of the FSC and concludes that these lavas possess an equivalent, but somewhat reduced, elemental subduction signature to the Tonga Arc sampled immediately to the south. This is unlike most BABB, including the MTJ to the north, which tend to have largely MORBlike major element characteristics, while still exhibiting the effects of a subduction-related flux in the form, for example, of enrichments in LILE (e.g. Lau Basin; Pearce et al., 1994; Macpherson and Mattey, 1998). The similarity of arc and FSC magmas is proposed to result from the proximity of the FSC to the arc, and therefore the similar depth-to-the-slab in the region (Keller et al., 2008). In addition, magmatism in the arc at the same latitude as the FSC appears to have ceased, with the melts instead refocused into the FSC.

\subsection{Tonga (Tofua) Arc}

Volcano A magmas have elevated $\mathrm{SiO}_{2}$ contents for a given $\mathrm{MgO}$ and relatively high $\mathrm{Ca}$ (Fig. 3) giving them

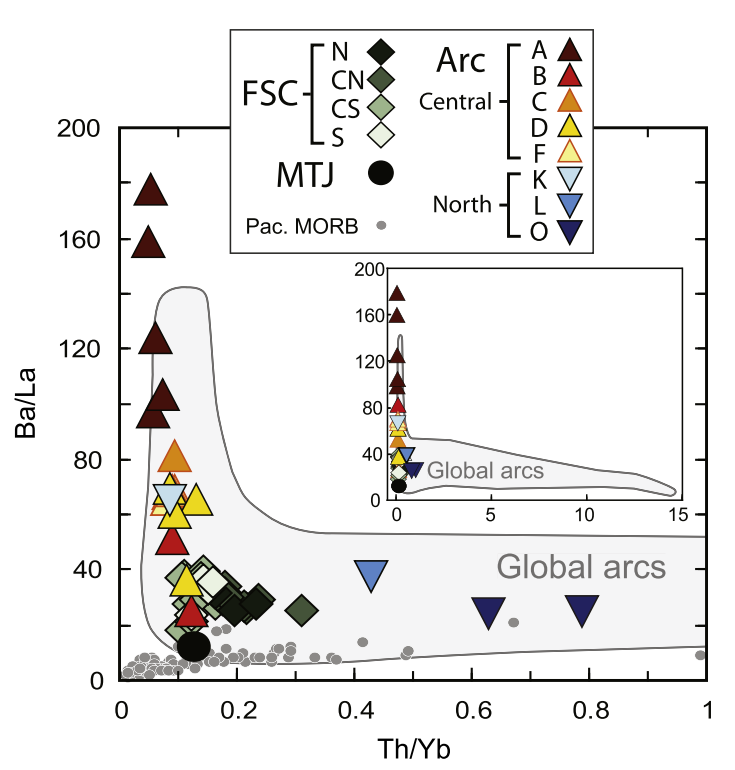

Fig. 3. $\mathrm{MgO}$ vs. $\mathrm{SiO}_{2}$ in lavas from the Tonga Arc, Fonualei Spreading Centre (FSC) and the Mangatolu Triple Junction, compared to MORB (PETDB database). Boninites and other Mgrich lavas with high $\mathrm{Si} / \mathrm{Mg}$ are present in the central and northern $\operatorname{arc}($ Volcanoes $\mathrm{A}, \mathrm{L}$ and $\mathrm{O}$ ) and the more northerly parts of the FSC. Arc rocks from Grenada and Izu-Bonin are also shown (Woodland et al., 2002). (For interpretation to colours in this figure, the reader is referred to the web version of this paper.) 
high-Ca boninitic affinity. Volcano $\mathrm{L}$ and $\mathrm{O}$ also have a degree of boninitic affinity similar to some FSC magmas. Volcano A lavas do not have the characteristic U-shaped REE profiles of some boninites and instead have similar REE patterns to N-MORB with low $\mathrm{La}_{\mathrm{N}} / \mathrm{Sm}_{\mathrm{N}}$ of $0.61-0.66$ (Cooper et al., 2010), indicating a depleted source despite probable LREE enrichment by means of a slab flux.

The strength of the subduction signature, and its nature, varies with latitude along the arc. The central arc volcanoes (A, B, C, D, and F), which span latitudes from Tongatapu to Fonualei (150 km to north and south of Tofua) possess some of the most extreme $\mathrm{Ba} / \mathrm{La}$ ratios of global arc magmas (up to 180 - 20 times greater than typical MORB; Fig. 2). Such high ratios in rocks with $>8 \% \mathrm{MgO}$ results from severe prior melt depletion of the mantle wedge and extensive preferential fluxing of LILE into the mantle wedge by slab fluids (Crawford et al., 1989; Cooper et al., 2010). Their low $\mathrm{Th} / \mathrm{Yb}$ ratios, comparable to MORB, indicate the absence of a significant flux from subducted sedi- ment. Of the northern arc volcanoes, Volcano $\mathrm{K}$ is most similar to central magmas in terms of $\mathrm{Ba} / \mathrm{La}$ and $\mathrm{Th} / \mathrm{Yb}$ systematics, and other indicators of mantle depletion, slab fluid flux and sediment input. The other northern volcanoes, $\mathrm{L}$ and $\mathrm{O}$, have less extreme $\mathrm{Ba} / \mathrm{La}$ ratios, similar to or lower than some Mariana Arc basalts (Elliott et al., 1997). Their higher $\mathrm{Th} / \mathrm{Yb}$ indicates a contribution from sediment. Negative $\mathrm{Nb}-\mathrm{Ta}$ anomalies are less extreme than in central arc volcanics, despite comparable prior melt depletion, and this has been ascribed to the influence of the Samoan plume or subducted Louisville volcaniclastic sediment (Turner and Hawkesworth, 1997; Regelous et al., 2008).

\subsection{Sulphur concentrations}

Available data for the Tonga Arc indicate that sulphur and other volatiles have been strongly affected by syn-eruptive degassing. Arc whole-rocks contain $<50 \mu \mathrm{g} / \mathrm{g} \mathrm{S}$,
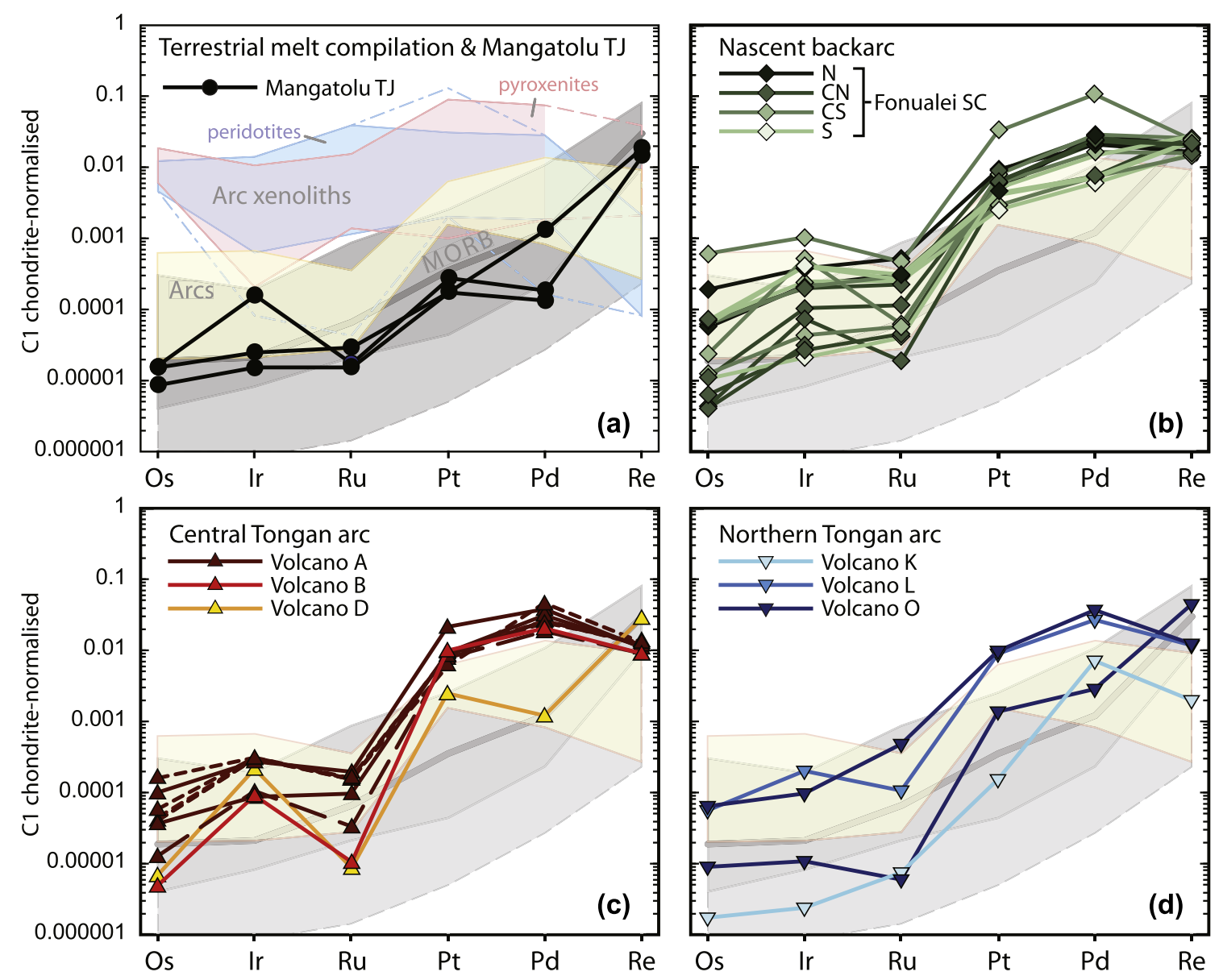

Fig. 4. PGE patterns of Tonga Arc, Fonualei Spreading Centre (FSC) and Mangatolu Triple Junction (MTJ) lavas relative to other terrestrial melts. a) MTJ lavas are largely MORB-like in their PGE patterns, with the exception of one positive Ir anomaly. Fields for published terrestrial melts: mid-ocean ridge basalt (thick grey line - mean, dark grey field - typical range, light grey - full range, Rehkämper et al., 1999; Bezos et al., 2005; Gannoun et al., 2007; Dale et al., 2008), arc magmas (Izu-Bonin, Lesser Antilles, Woodland et al., 2002), peridotite and pyroxenite arc xenoliths (McInnes et al., 1999; Kepezhinskas et al., 2002, respectively), (b) FSC lavas, particularly those from the central area, have elevated Pt and Pd concentrations and Pt/Ru ratios compared to typical MORB. (c) Central arc lavas display extremely high Pt and Pd contents and $\mathrm{Pt} / \mathrm{Ru}$ ratios, Ir/Os is also commonly elevated. (d) Northern arc lavas also have high PPGE, but typically less extreme Pt/Ru than mid-arc samples. (For interpretation to colours in this figure, the reader is referred to the web version of this paper.) 
compared with up to $2000 \mu \mathrm{g} / \mathrm{g}$ S for olivine-hosted melt inclusions (Cooper et al., 2010). Hence, whole-rock S contents do not provide information on pre-eruptive magma evolution and sulphide precipitation and so additional $\mathrm{S}$ data have not been obtained. Published $\mathrm{S}$ concentrations for the FSC are also very low (25-160 $\mu \mathrm{g} / \mathrm{g}$; Table 1) (Keller et al., 2008). Given the controls of melt composition and oxygen fugacity $\left(\mathrm{fO}_{2}\right)$ on $\mathrm{S}$ solubility (Mavrogenes and O'Neill, 1999; Jugo, 2009), even arc melt inclusions with the highest $\mathrm{S}$ contents $(2000 \mu \mathrm{g} / \mathrm{g})$ may not have been sulphide saturated.

\section{DATA}

\subsection{Highly siderophile elements}

\subsubsection{Highly siderophile element abundances and patterns}

The two lavas analysed from the MTJ have HSE concentrations and inter-element fractionation comparable to MORB (Table 1 and Fig. 4a); Pt and Pd concentrations are substantially higher $(0.1-0.8 \mathrm{ng} / \mathrm{g})$ than $\mathrm{Os}$ and $\mathrm{Ru}$ $(<0.025 \mathrm{ng} / \mathrm{g})$. Re concentrations are at the low end of the MORB range (0.5-0.7 ng/g; c.f. Sun et al., 2003b; Gannoun et al., 2007). There is a considerable positive Ir anomaly in one of the whole rocks (ND-70-01), defined by high Ir relative to both $\mathrm{Os}$ and $\mathrm{Ru}$, with $\mathrm{Ru}$ being relatively low compared to most mafic mantle melts. This anomaly is absent from the glass analysis.

Fonualei Spreading Centre samples display a greater degree of inter-element HSE fractionation than those from the MTJ or MORB (Fig. 4b). Os and Ru concentrations largely fall within the MORB range but most are somewhat higher than the MTJ samples, while also having typically higher $\mathrm{MgO}$ (>8 wt.\%). Platinum and Pd contents, however, are one to two orders of magnitude higher than MTJ lavas (up to 32 and $61 \mathrm{ng} / \mathrm{g}$, respectively). This enrichment gives rise to $\mathrm{Pt} / \mathrm{Os}$ and $\mathrm{Pt} / \mathrm{Ru}$ ratios that are considerably greater than MORB (FSC: Pt/Ru up to 196, weighted mean 45; MORB: up to 60, mean 7; Rehkämper et al., 1999; Bezos et al., 2005). Rhenium concentrations are within, but mostly at the lower end of the range of MORB (0.55$1.05 \mathrm{ng} / \mathrm{g}$ ) and display a weak positive co-variation with dredge depth below sea level (Fig. 5a). Most samples have $\mathrm{Ir} / \mathrm{Os}$ and $\mathrm{Ir} / \mathrm{Ru}$ that are significantly higher than typical mantle and mantle-derived melts (FSC chondrite-normalised Ir/Os: 1.7-22; mantle 1, e.g. Becker et al., 2006).

Central arc lavas (Volcanoes A, B, and D) display the greatest PPGE(Pt-Pd)/IPGE(Os-Ir-Ru) fractionation measured in this study (Fig. 4c) and amongst the most extreme reported for terrestrial melts (cf. low Ti lavas in Hamlyn et al., 1985). The ranges of Pt and Pd concentrations both extend up to $21 \mathrm{ng} / \mathrm{g}$, more than 25 times the MORB mean for both elements $(\sim 0.43 \mathrm{ng} / \mathrm{g} \mathrm{Pt}, \sim 0.75 \mathrm{ng} /$ g Pd; Rehkämper et al., 1999; Bezos et al., 2005; Dale et al., 2008), while Os and $\mathrm{Ru}$ concentrations are within the MORB range (Fig. 4c). Consequently, the extreme Pt/ $\mathrm{Ru}(67-1300)$ are higher than any previously reported terrestrial melt (Fig. 9, c.f. MORB, max. 60; Bezos et al., 2005), and $\mathrm{Pd} / \mathrm{Ru}$ ratios are higher still (107-1520). Northern arc magmas also display PPGE/IPGE fractionation sig-
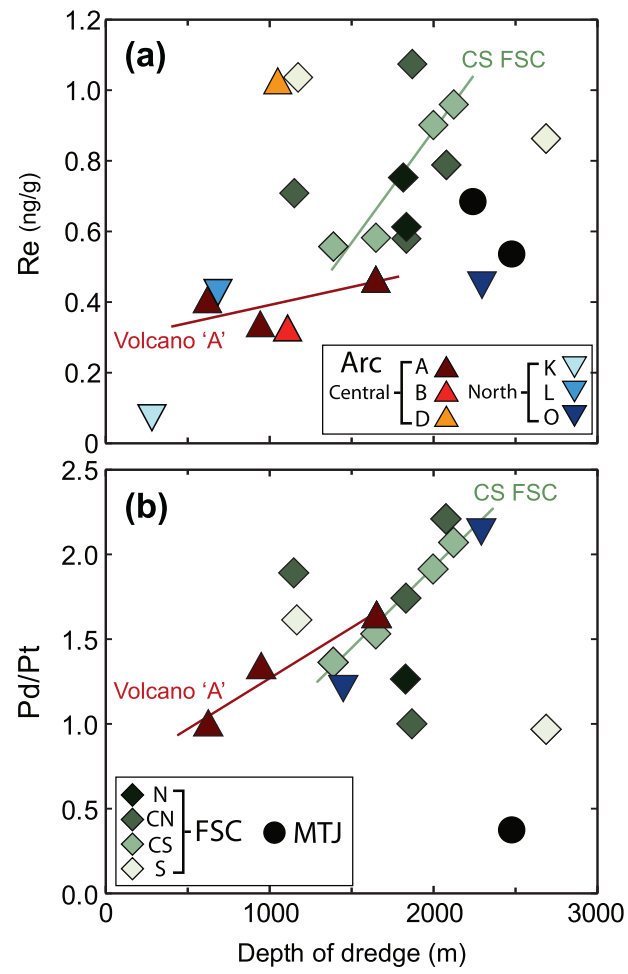

Fig. 5. Water depth at dredge site (as a proxy for eruption depth) vs. (a) Re content, and (b) Pd/Pt. There is a weak overall covariation of Re concentration and water depth, with stronger covariations in some sub-suites (CS FSC and central arc) - cf. Re vs. $\mathrm{MgO}$ in Fig. 6. The ratio of Pd to Pt co-varies positively with water depth in some suites, suggesting that Pd is preferentially lost, relative to $\mathrm{Pt}$, during syn-eruptional magma degassing. However, the absence of co-variation in some suites (e.g. CS FSC), and between suites, indicates other controlling factors. Sub-suites with two or fewer samples omitted for clarity from (b). (For interpretation to colours in this figure, the reader is referred to the web version of this paper.)

nificantly greater than typical MORB (Fig. 4d), though not as high as central arc magmas. Positive chondrite-normalised Ir anomalies are present in all lavas from all central volcanoes, and half of the northern arc lavas. Rhenium concentrations differ across all arc lavas, at least in part they vary positively with water depth of the dredge (therefore eruption) (Fig. 5a). Ratios of Pd to Pt also co-vary with water depth of eruption within most sample areas (e.g. Volcano A), and in the arc-FSC suite as a whole (Fig. 5b).

\subsection{2. $\mathrm{MgO}-\mathrm{Ni}-\mathrm{Cu}-\mathrm{HSE}$ systematics}

Nickel displays compatible behaviour in all Tongan suites, similar to the global compilation (Fig. 6), though in detail $\mathrm{Ni}$ concentrations are lower, particularly in the arc lavas, than in most MORB at the same $\mathrm{MgO}$ content. In MTJ lavas, and in MORB systems, $\mathrm{Cu}$ concentrations typically decrease appreciably between 7 and $8 \mathrm{wt} . \%$ $\mathrm{MgO}$, indicating compatible behaviour in many MORB at this $\mathrm{MgO}$ content (Fig. 6). In contrast, in the arc and 

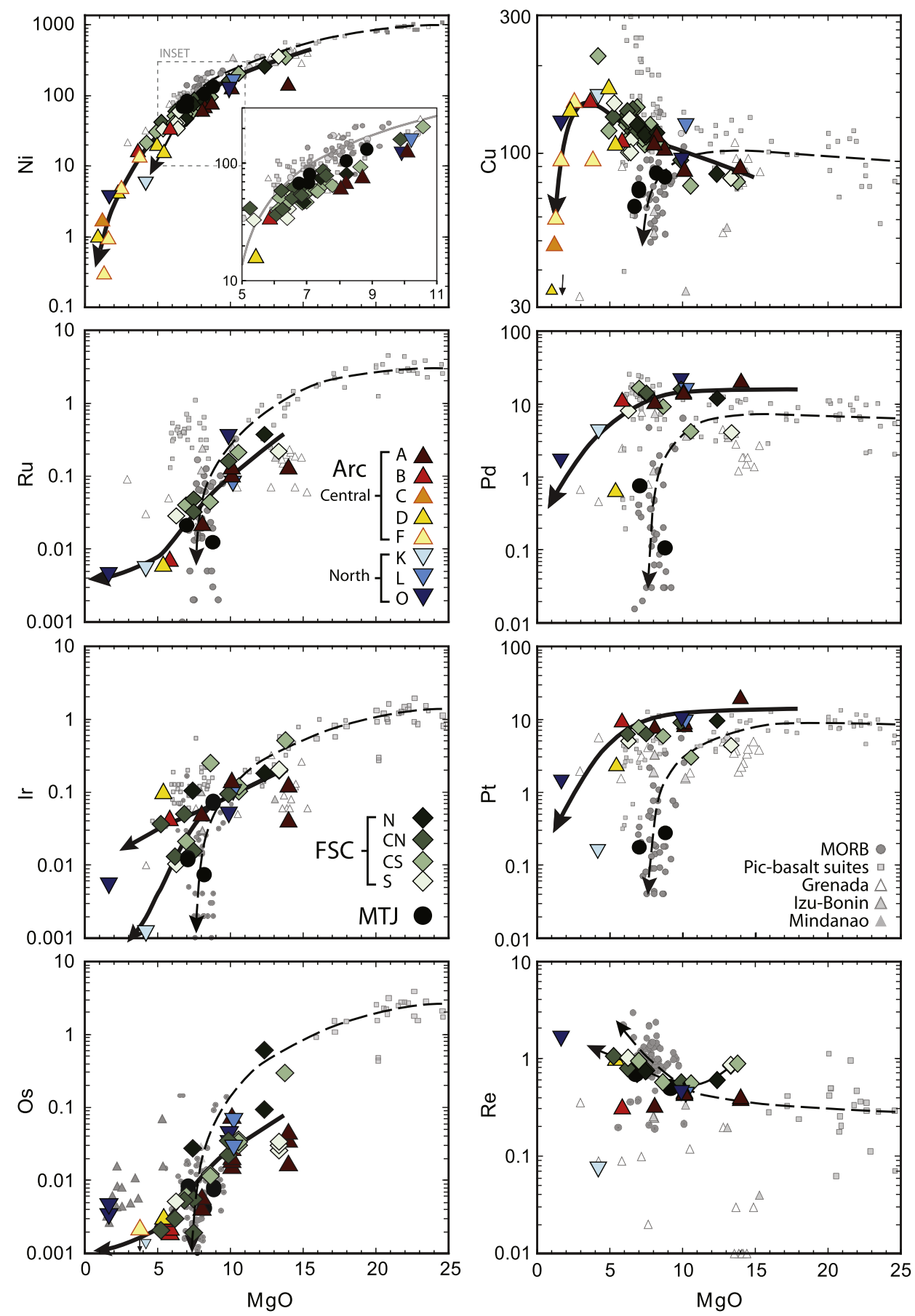

Fig. 6. $\mathrm{Ni}, \mathrm{Cu}(\mu \mathrm{g} / \mathrm{g})$ and $\mathrm{HSE}$ concentrations $(\mathrm{ng} / \mathrm{g})$ as a function of $\mathrm{MgO}$ content (wt.\%) in lavas from the Tonga Arc, FSC and MTJ. Arrows are interpretations of behaviour during magma evolution: continuous lines for Tongan melt evolution, dashed for MOR systems. Global dataset for MORB (Rehkämper et al., 1999; Bezos et al., 2005; Gannoun et al., 2007; Dale et al., 2008), North Atlantic plume-related picrite-basalt sequences (Iceland/Greenland, Momme et al., 2002, 2003; Dale et al., 2009b), and arcs (Woodland et al., 2002; Dreher et al., 2005). (For interpretation to colours in this figure, the reader is referred to the web version of this paper.)

FSC suites $\mathrm{Cu}$ behaves moderately incompatibly across a range of $\mathrm{MgO}$ until evolved magma compositions of $\mathrm{MgO} \leqslant 3 \mathrm{wt} . \%$ are reached, at which point $\mathrm{Cu}$ behaves compatibly.

The systematics of Ru and Os in MTJ, MORB and most magma suites from the literature closely follow those of $\mathrm{Ni}$, as previously noted for Os (e.g. Burton et al., 2002). However, the FSC and arc samples typically have significantly lower $\mathrm{Ru}$ (and Os) concentrations at high $\mathrm{MgO}$ compared to magmas from different geological environments, and the co-variation of $\mathrm{Ru}$ with $\mathrm{MgO}$ shows a less rapid decrease of $\mathrm{Ru}$ than MORB systems, over the same range 
of $\mathrm{MgO}$ content (Fig. 6). This feature is even more marked in two other arc settings, namely Grenada (Lesser Antilles Arc) and the Izu-Bonin Arc (Woodland et al., 2002). Iridium behaves similarly but with more variation and typically higher abundances than Os and $\mathrm{Ru}$.

The two MTJ samples plot within the MORB field in $\mathrm{Pt}-$ and $\mathrm{Pd}-\mathrm{MgO}$ space (Fig. 6). In contrast, $\mathrm{Pt}$ and $\mathrm{Pd}$ are more enriched in the most $\mathrm{MgO}$-rich arc and northerly FSC magmas than in magmas with comparable $\mathrm{MgO}$ from the literature. In addition, $\mathrm{Pd}$ and $\mathrm{Pt}$ are only mildly compatible above $\sim 6 \mathrm{wt} . \% \mathrm{MgO}$ in Tongan Arc- and most FSC magmas, whereas both elements behave compatibly below $\sim 12-13 \mathrm{wt} . \% \mathrm{MgO}$ in most other terrestrial systems, including MORB (Fig. 6). Arc- and most FSC magmas (particularly more northerly ones) also have lower $\mathrm{Cu} / \mathrm{Pd}$ (and $\mathrm{Cu}$ / $\mathrm{Pt}$ ) ratios for a given $\mathrm{MgO}$ than literature data and $\mathrm{MTJ}$ lavas (Fig. 7). This is true at $\sim 13 \mathrm{wt} . \% \mathrm{MgO}$, suggesting this is a primary feature. As $\mathrm{MgO}$ content decreases, $\mathrm{Cu} / \mathrm{Pd}$ in arc magmas increases at a similar rate to MORB and other terrestrial magmas, until approximately $10 \mathrm{wt} . \% \mathrm{MgO}$, at which point the MORB system rapidly evolves to much higher $\mathrm{Cu} / \mathrm{Pd}$ than the arc and FSC system magmas.

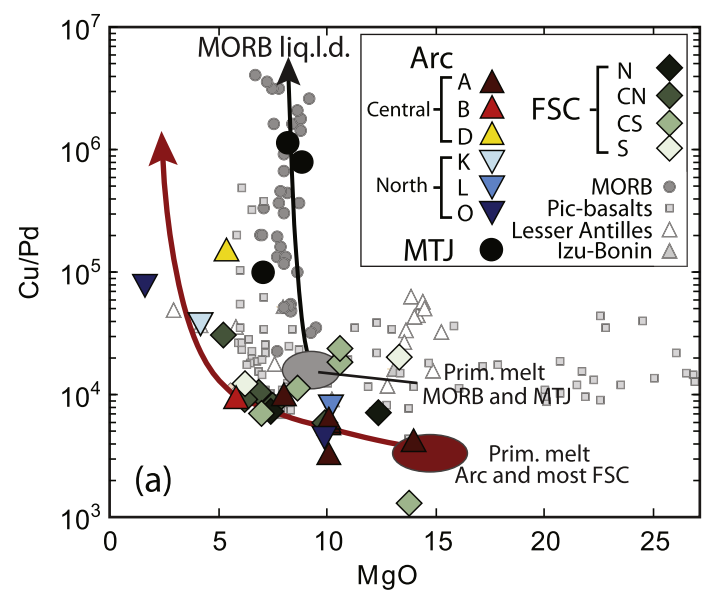

Fig. 7. $\mathrm{Cu} / \mathrm{Pd}$ in Tongan magmas as a function of differentiation, indicated by $\mathrm{MgO}$ content. $\mathrm{Cu} / \mathrm{Pd}$ (and $\mathrm{Cu} / \mathrm{Pt}$ ) ratios are lower in primitive (primary?) arc melts, and some FSC melts, than in typical mid-ocean ridge magma systems, and arc magmas also tend to evolve less extreme $\mathrm{Cu} / \mathrm{PPGE}$ ratios during fractional crystallisation. The modelled effects of differing sulphide fractionation (arrows) indicate that this can be explained by sulphur undersaturation in the arc melts (and some FSC melts), which results in retention of $\mathrm{Pd}$ and $\mathrm{Pt}$ in the melt rather than their preferential partitioning into precipitating sulphide as the melt becomes sulphur saturated. Given the complexities of sulphur solubility (as a function of $\mathrm{fO}_{2}, \mathrm{Fe}$ content, $\mathrm{T}, \mathrm{P}$ ) the model assumes, rather than predicts, minimal sulphide fractionation at $\mathrm{MgO}>\sim 5 \mathrm{wt} . \%$ in the arc magmas, but significant sulphide fractionation in MORB at $\mathrm{MgO} \sim 9 \mathrm{wt} . \%$ and below. The parameters are given in Table 2. The increase in $\mathrm{Cu} / \mathrm{Pd}$ at high $\mathrm{MgO}$ in the arc magmas requires either a very small proportion of sulphide precipitation (an order of magnitude less than for MORB) or Pd partitioning into other phases. The evidence from digestion experiments (see Methods) is that more than half the Pd budget is hosted by silicates, so in this case no sulphide precipitation is required above $5 \mathrm{wt} \% \mathrm{MgO}$. Literature references see Fig. 6. (For interpretation to colours in this figure, the reader is referred to the web version of this paper.)
Despite the weak co-variation of Re concentration with water depth of eruption (Fig. 5a), Re varies systematically with $\mathrm{MgO}$ content in FSC lavas and some arc samples, initially behaving compatibly during magma differentiation above $10 \mathrm{wt} . \% \mathrm{MgO}$, and becoming significantly incompatible at lower $\mathrm{MgO}$ (Fig. 6).

\subsection{Osmium isotopes}

Most Tongan Arc lavas fall on a single, broad trend of increasingly radiogenic isotopic signature with decreasing Os abundance (Fig. 8). This trend is ubiquitous for oceanic magmas, including OIB (e.g. Reisberg et al., 1993; Widom, 1997), with the possible exception of MORB when samples are carefully characterised for alteration and age (cf. Gannoun et al., 2007). The Tongan isotopic values are lower, for a given Os concentration, than available data for the Lesser Antilles Arc (Woodland et al., 2002), but comparable to adakitic rocks from the East Philippine Arc (Dreher et al., 2005). The most Os-rich sample has a ${ }^{187} \mathrm{Os} /{ }^{188} \mathrm{Os}$ ratio indistinguishable from the lowest values for MORB (0.126, cf. Gannoun et al., 2007). Less Os-rich samples have more radiogenic Os, but with few exceptions they are within the range of MORB at Os concentrations greater than $0.02 \mathrm{ng} / \mathrm{g}\left({ }^{187} \mathrm{Os} /{ }^{188} \mathrm{Os}\right.$ : $\left.0.126-0.132\right)$. Three of the four replicate whole-rock analyses of ND-04-01 (Volcano A) give an apparent isochron age of $6.5 \pm 0.4 \mathrm{Ma}$ (initial ${ }^{187} \mathrm{Os} /{ }^{188}$ Os: 0.1280 , MSWD: 0.16), which is of uncertain reliability given it is only 3 data, but is older than expected

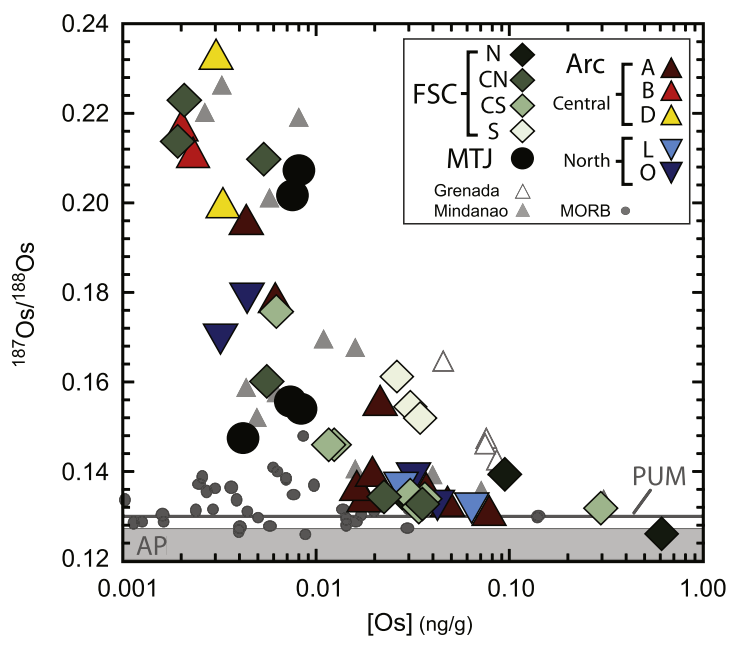

Fig. $8 .{ }^{187} \mathrm{Os} /{ }^{188} \mathrm{Os}$ as a function of Os content $(\mathrm{ng} / \mathrm{g})$ in lavas from the central and northern Tonga Arc, the FSC and the MTJ. Increasingly radiogenic isotopic signature with decreasing Os abundance reflects either preferential sampling of minor radiogenic mantle components by smaller percentage melts (lower Os content) and/or shallow-level contamination (crust or seawater). Samples with Os $>0.02 \mathrm{ng} / \mathrm{g}$ are typically indistinguishable from MORB. MORB (Gannoun et al., 2007), other arcs (Woodland et al., 2002; Dreher et al., 2005), primitive upper mantle (Meisel et al., 2001b) and abyssal peridotite (AP, Roy-Barman and Allegre, 1994; Snow and Reisberg, 1995; Harvey et al., 2006) shown for comparison. (For interpretation to colours in this figure, the reader is referred to the web version of this paper.) 
given the freshness of the sample (Fig. S2). It may instead be a mixing line between the initial composition and a radiogenic contaminant (crust?).

\section{DISCUSSION}

\subsection{Behaviour of HSEs accompanying arc magma evolution and their inferred mineral-scale distribution}

The IPGE (Os, Ir, Ru) behave compatibly during fractional crystallisation (Barnes et al., 1985), as demonstrated in the Tongan dataset by the positive co-variation of their concentrations with $\mathrm{MgO}$ (Fig. 6). The similarity of IPGE and $\mathrm{Ni}$ behaviour with respect to $\mathrm{MgO}$, in most basic magma systems, indicates that their concentrations appear to be largely controlled by olivine crystallisation and concomitant $\mathrm{Fe}-\mathrm{Ni}$-sulphide precipitation (Fig. 6) (e.g. Hamlyn et al., 1985; Burton et al., 2002), although PGE-rich microphases have been proposed for some komatiites (Puchtel and Humayun, 2000; Puchtel et al., 2004; Barnes and Fiorentini, 2008). Compared to MORB and other terrestrial mantle melts, $\mathrm{Ru}$, Ir and Os concentrations in Tongan Arc magmas (and rocks from other arcs) decrease less rapidly with decreasing $\mathrm{MgO}$ content, indicating a lower bulk partition coefficient for these elements in the arc system. Platinum and Pd in the arc and FSC suites are both mildly compatible to mildly incompatible across a large range of $\mathrm{MgO}$ contents down to approximately $6 \mathrm{wt} . \% \mathrm{MgO}$. This also contrasts with magmatism from most terrestrial settings, including the Mangatolu Triple Junction, where Pt is compatible below $22 \mathrm{wt} . \% \mathrm{MgO}$ and $\mathrm{Pd}$ below 10 13 wt. $\% \mathrm{MgO}$. The atypical incompatibility of $\mathrm{Pt}$ and $\mathrm{Pd}$ in Tongan Arc magmas accentuates the effect of increasing PPGE/IPGE during differentiation of basaltic magma (Fig. 9; e.g. Barnes et al., 1985).

The less compatible behaviour of the PGE during magma evolution can be ascribed to sulphide undersaturation

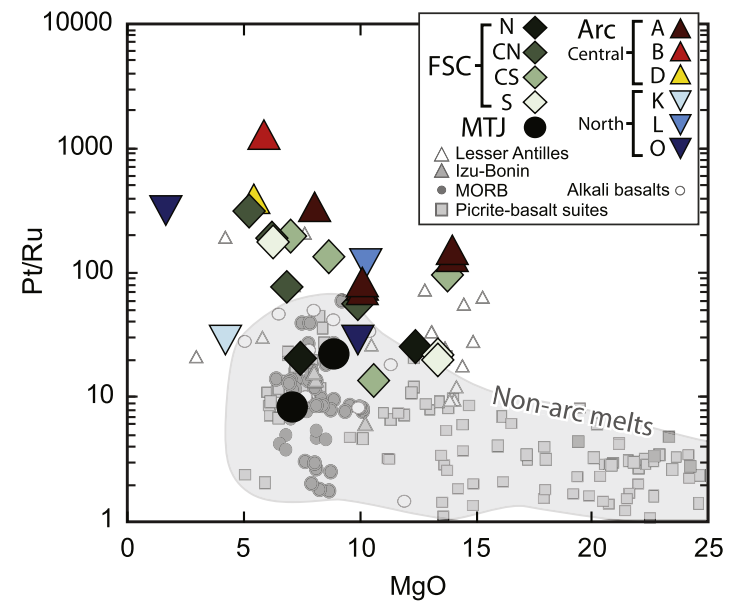

Fig. 9. $\mathrm{Pt} / \mathrm{Ru}$ as a function of $\mathrm{MgO}$ content. Note increasing $\mathrm{Pt} /$ $\mathrm{Ru}$ during magma differentiation, but elevated $\mathrm{Pt} / \mathrm{Ru}$ in primitive (primary?) melts. For literature references see Fig. 6. (For interpretation to colours in this figure, the reader is referred to the web version of this paper.) of these arc melts and therefore the absence of significant sulphide precipitation during most of their evolution. Whole-rock sulphur concentrations unfortunately do not shed light on the likelihood of pre-eruptive sulphide undersaturation because volatile loss during degassing has depleted S in all arc lavas (Cooper et al., 2010) and probably many FSC samples. Some very high S contents have been found in melt inclusions from Tongan Arc magmas ( $2000 \mu \mathrm{g} / \mathrm{g}$; Cooper et al., 2010) but as S solubility increases with increasing oxygen fugacity $\left(\mathrm{fO}_{2}\right)$ due to the presence of $\mathrm{SO}_{4}{ }^{2-}$ (e.g. Jugo, 2009), sulphide saturation is not necessarily attained at such concentrations. A more robust way of looking at sulphide saturation is through the behaviour of $\mathrm{Cu}$ and $\mathrm{Pd}$ with decreasing $\mathrm{MgO}$. Sulphide precipitation leads to compatible behaviour of chalcophile $\mathrm{Cu}$ (as seen in MORB data), whereas in the Tongan suites $\mathrm{Cu}$ is incompatible above $\sim 3 \mathrm{wt} . \% \mathrm{MgO}$ (Fig. 6). Moreover, as partition coefficients between sulphide and silicate melt are much greater for $\mathrm{Pd}$ than for $\mathrm{Cu}\left(\mathrm{D}_{\text {sulphide- }}\right.$ sil $=3.5 \times 10^{4}$ for $\mathrm{Pd}, \sim 1000$ for $\mathrm{Cu}$ (Peach et al., 1990)), any sulphide precipitation will result in a significant increase in $\mathrm{Cu} / \mathrm{Pd}$, which is not seen above $5 \mathrm{wt} . \% \mathrm{MgO}$ (see modelled melt evolution, Fig. 7). Such undersaturation, even after significant fractional crystallisation, is consistent with elevated oxygen fugacity and the possible complete consumption of sulphide in the depleted boninite source region. Below 3 wt. $\% \mathrm{MgO}, \mathrm{Cu}$ behaves compatibly in the arc suite (Fig. 6), implying incorporation into sulphide. At the same time, $\mathrm{Fe}, \mathrm{Ti}$ and $\mathrm{V}$ concentrations decrease (not shown), indicating crystallisation of Ti-rich magnetite. The reduced $\mathrm{Fe}$ content of the melt and lower $\mathrm{fO}_{2}$ as a consequence of preferential incorporation of ferric iron into magnetite then leads to sulphide saturation and precipitation (Sun et al., 2004; Jenner et al., 2010).

Digestion experiments with and without hydrofluoric acid can provide further information on HSE behaviour. It has previously been demonstrated that Re may be commonly hosted by silicate phases in both mantle and magmatic systems (Burton et al., 2000; Dale et al., 2009a, respectively), and that extraction of Re from certain rocks is incomplete without dissolving silicate phases (Meisel et al., 2009). Nonetheless, comparison of digestions withand without-HF in this study were surprising in the effect that HF had on HSE extraction efficiency (see Analytical methods, Table S1 and Fig. S1). Assuming total extraction by combined $\mathrm{HF}$-aqua regia digestion, in extreme cases aqua regia alone extracted as little as $7 \%$ and $22 \%$ of the total $\mathrm{Re}$ and $\mathrm{Pt}$, respectively, and only $8 \%$ of the extremely chalcophile Pd. This suggests a strong mineralogical control on HSE extraction from these samples, as extensive tests on other rock suites have not revealed such significant discrepancies (Dale et al., 2008, 2009a). There is also a marked variation in extraction efficiency according to tectonic setting in our Tongan samples: PGE (but not Re) are completely extracted from MTJ glassy lavas without HF, whereas all FSC and arc samples, particularly Volcano A lavas, display variable but consistently incomplete HSE extraction without HF. This variation in extraction efficiency broadly co-varies negatively with $\mathrm{Ba} / \mathrm{La}$ (Fig. S1), suggesting that it is related to the degree of slab flux contribution to the 
source, although a source depletion effect cannot be ruled out. Increased oxygen fugacity due to slab flux input could affect extraction efficiency by changing the solubility of sulphur in the melt, and hence whether sulphide precipitates and hosts HSEs.

Samples from the triple junction contain $\mathrm{S}$ concentrations ( $\sim 900 \mu \mathrm{g} / \mathrm{g} \mathrm{S}$, Keller et al., 2008) similar to primitive MORB (1000-1300 $\mu \mathrm{g} / \mathrm{g} \mathrm{S}$, Mathez, 1976) and thus, like MORB, these samples would likely have experienced sulphide saturation and precipitation, into which the HSEs would be strongly partitioned. Sulphide is readily digested in aqua regia, accounting for the very good extraction of HSEs from these rocks. The extremely poor HSE extraction in many arc and FSC samples must be due to sulphide undersaturation and these elements being hosted by phases other than sulphide: silicate or oxide phases, glass or microplatinum group minerals (PGMs). Indeed, sulphides have not been observed after close scrutiny of all thin sections in transmitted and reflected light. A high-temperature digestion in aqua regia should successfully break down oxide phases and PGM (Meisel et al., 2001a), so the requirement for $\mathrm{HF}$, which attacks $\mathrm{Si}$ bonds, strongly suggests that a significant proportion of some HSEs (particularly Re and PPGE: Pt, Pd) is hosted by silicate (either in crystals or in glass) or possibly in micro-PGM within silicate. The concentrations of the IPGE (Os, Ir and Ru), at least, are probably not high enough to precipitate PGM at the estimated $\mathrm{fO}_{2}$ of $\sim 0.5 \log$ units above the FMQ (fayalite-magnetite-quartz) buffer (cf. Brenan et al., 2005).

The majority of whole-rock samples from all settings studied here possess chondrite-normalised $\mathrm{Ir} / \mathrm{Ru}$ ratios which are higher than typical MORB. However, the glasses analysed do not have such high $\mathrm{Ir} / \mathrm{Ru}$, a feature previously identified in MORB and ascribed to Ir nuggets within the pillow interior (Bezos et al., 2005). However, if Ir is concentrated in dispersed micro-nuggets of Ir alloys/metal then excellent reproducibility of $1.5 \mathrm{~g}$ replicate analyses of ND$04-01$ ( $5 \%$ for $\operatorname{Ir}, n=4,2 \mathrm{SD}$ ) would seem unlikely. In fact, the reproducibility of Ir is far better than for all other HSEs except $\operatorname{Re}$ (and $\mathrm{Ru}$ ), for which silicate is known to be a significant host in typical mantle melts (Gannoun et al., 2004; Dale et al., 2009a). So, combined with the evidence of incomplete Ir extraction without HF dissolution, we instead suggest that the discrepancy between whole rock and glass in Tongan lavas is attributable to partitioning of Ir into silicate phases.

Rhenium has been found to be volatile during magmatic degassing at depths less than 1000 mbsl (Lassiter, 2003; Sun et al., 2003a). Samples analysed here were typically erupted at water depths greater than $1000 \mathrm{~m}$, meaning that volatile loss of Re should be limited, but the greater volatile content of arc and FSC magmas may initiate degassing at depths greater than in water-poor magmatic provinces such as Hawaii (e.g. Dixon and Stolper, 1995). The low Re contents of arc lavas likely reflects, at least in part, loss during syneruptive degassing, but two observations suggest that this is unlikely to be the only controlling factor and may only play a limited role in the more deeply erupted and more Re-rich FSC and MTJ lavas. Firstly, there is systematic variation of $\mathrm{Re}$ with $\mathrm{MgO}$ in FSC samples which would be masked by significant degassing; and secondly, we ob- serve positive correlations between $\mathrm{Re}$ and the similarly compatible, but non-volatile Yb (Hauri and Hart, 1997). Rhenium concentrations and $\mathrm{Re} / \mathrm{Yb}(\sim 0.25$; given as $\mathrm{Re}$ $\mathrm{ppb} / \mathrm{Yb} \mathrm{ppm}$ ) of MTJ samples are at the low end of the un-degassed MORB range (Fig. 10), and hence are consistent with other geochemical indicators which suggest a MORB-like source and eruption history for MTJ magma. In contrast, the FSC samples have similar Re contents, lower $\mathrm{Yb}$, and consequently significantly higher $\mathrm{Re} / \mathrm{Yb}(\sim 0.8)$, intermediate between MORB/MTJ and arc melt inclusions ( $\mathrm{Re} / \mathrm{Yb} \sim 2$, Sun et al., 2003a). Elevated $\mathrm{Re} / \mathrm{Yb}$ could be produced either by Re enrichment of a source that has been depleted in incompatible elements such as $\mathrm{Re}$ and $\mathrm{Yb}$, or by retention of $\mathrm{Yb}$ but not $\mathrm{Re}$ during melting of garnet-bearing mantle. The prior melt depletion of the Tongan Arc mantle (e.g. Cooper et al., 2010) would result in the limited presence of garnet and severe depletion of incompatible $\mathrm{Re}$ (cf. Re concentrations in depleted abyssal peridotites (0.074 ng/g Re, Harvey et al., 2006) compared to putative primitive mantle (0.32 ng/g Re, Becker et al., 2006)). Hence, we attribute the elevated $\mathrm{Re} / \mathrm{Yb}$ to $\mathrm{Re}$ enrichment of a depleted source. Such enrichment has previously been observed in arc and backarc melt inclusions (Sun et al., 2003a,b), probably as a consequence of a Re flux from the slab (e.g. Dale et al., 2007).

An additional mechanism for increased Re concentrations in arc magmas is the reduced stability of mantle sulphide due to elevated oxygen fugacity (Righter et al., 2008). While this cannot be discounted as a contributor to the enrichment discussed above, the absence of higher

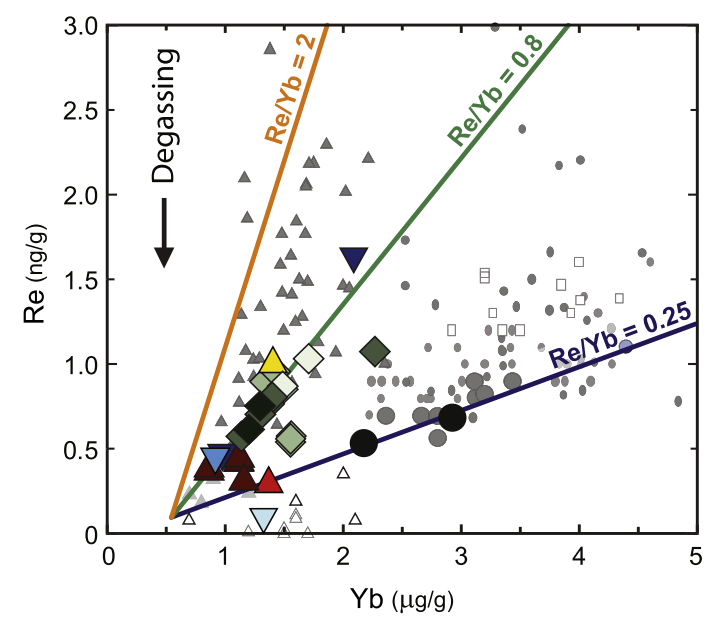

Fig. 10. Rhenium concentrations for Tongan Arc, FSC and MTJ lavas as a function of the abundance of the similarly compatible element $\mathrm{Yb}$ (for symbols see previous figures). Note the higher Re/ $\mathrm{Yb}$ (given as Re ppb/Yb ppm) ratios of FSC lavas, in comparison to MORB. Literature data: large filled circles - MTJ, small filled circles - MORB, unfilled squares - Lau Basin basalts, unfilled triangles - Lesser Antilles (Grenada), light grey triangles - IzuBonin Arc, dark grey triangles (high $\mathrm{Re} / \mathrm{Yb}$ ) - arc melt inclusions (Woodland et al., 2002; Sun et al., 2003a,b; Gannoun et al., 2007). (For interpretation to colours in this figure, the reader is referred to the web version of this paper.) 
Re contents than MORB in any of the primitive arc or FSC lavas, suggests that this is not the dominant process controlling Re. Moreover, natural and experimental studies of the distribution of $\mathrm{Re}$ in mantle minerals and derived melts suggest that the Re budget may not be dominated by sulphide (Burton et al., 2000, 2002; Brenan, 2008; Dale et al., 2009a). Furthermore, Re becomes less chalcophile at elevated $\mathrm{fO}_{2}$ (Fonseca et al., 2007), thus reducing the potential effect of sulphide instability on Re content.

Good positive co-variations of $\mathrm{Pd} / \mathrm{Pt}$ with water depth in several individual magma groups from the Tonga Arc and FSC suggests that volatility may also be a controlling factor for Pd content. Mobility of Pd in sulphur-rich vapour phases and hydrothermal fluids has been observed experimentally, thermodynamically and in natural samples (Wood et al., 1989; Peregoedova et al., 2006; Barnes and Liu, 2012). Low $\mathrm{Pd} / \mathrm{Pt}$ in sub-aerially erupted lavas such as Grenada (Woodland et al., 2002), compared with deep submarine systems such as MORB, has also been observed. The loss of Pd in the Tongan magmas appears to occur to a depth of at least 2000 mbsl. - deeper than the limit for Re loss proposed for Hawaiian lavas ( 1000 m; Lassiter, 2003), although the higher volatile content of arc lavas will initiate degassing at greater depths. Assuming that Pt is not volatile, and that no volatile loss occurs at depths greater than 2000 mbsl., we estimate that $\mathrm{Pd}$ concentrations in the most shallowly erupted arc magmas have been depleted by $50 \%$ during degassing, but still remain amongst the highest for terrestrial melts.

In summary, the PGEs are less compatible during magma evolution in the Tonga Arc and FSC, compared to most other terrestrial systems including MORB. This is a consequence of sulphide undersaturation due to exhaustion of sulphide in the mantle source (see later) and/or the presence of a proportion of $\mathrm{S}$ in its more soluble sulphate form (520\%; Carroll and Webster, 1994; Jugo, 2009) due to elevated oxygen fugacity ( 0.5 FMQ; Keller et al., 2008). The requirement of full silicate dissolution suggests that silicate phases account for a significant proportion of the $\mathrm{Pt}$, $\mathrm{Pd}$, and Re budget (and perhaps Ir).

\subsection{Primitive melt HSE systematics in arc settings}

All arc-related melts reaching the surface have undergone some degree of fractionation and assimilation within the arc crust, but the primary geochemical signatures of the most magnesian rocks in this study (7-14 wt.\% MgO) are unlikely to have been comprehensively altered. Assuming that this is the case, we can constrain the primary mantle melting HSE characteristics, particularly as sulphide fractionation was absent at high $\mathrm{MgO}$ (see above) which could otherwise have exerted significant leverage on magmatic HSE concentrations. Here, average HSE abundances for each sub-area have been normalised to 'average' MORB (Fig. 11), only including samples with $>7 \mathrm{wt} . \% \mathrm{MgO}$ to reduce the effects of fractional crystallisation. While we recognise that these do not all represent primary melts, and that the absolute values for MORB may be subject to change given the relatively small dataset $(\sim 50)$, such a plot provides a strong comparison between primitive arc and MORB melts.

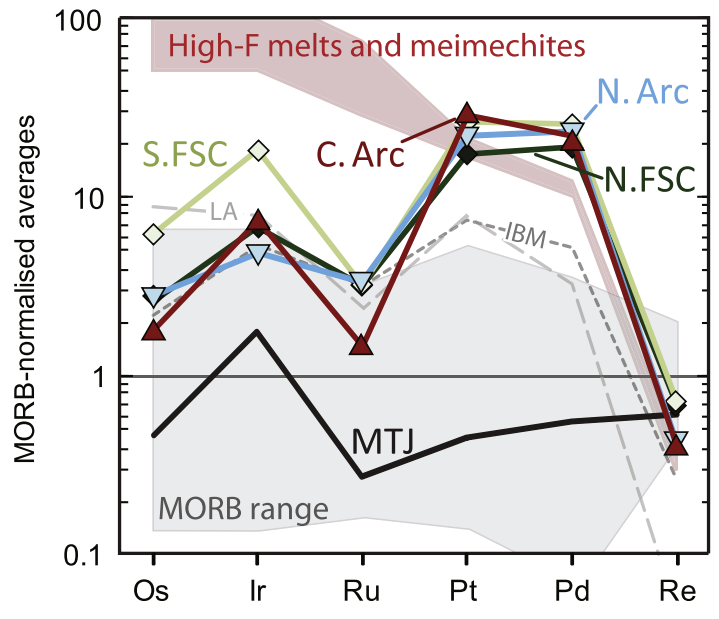

Fig. 11. MORB-normalised average HSE concentrations for the Tonga Arc (Central and Northern), Fonualei Spreading Centre (S FSC: south/central-southern; N FSC: central-northern/North), and MTJ. As PPGE/IPGE ratios tend to increase during magma evolution, samples with $\mathrm{MgO}<7 \%$ have been omitted. The comparison with high melt-fraction magmas, akin to Tongan rocks, illustrates that the Tongan pattern is at least as attributable to IPGE retention in the mantle source as it is to PPGE enrichment. MORB average from Rehkämper et al. (1999), Bezos et al. (2005), Gannoun et al. (2007), Dale et al. (2008); Izu-Bonin (IBM) and Lesser Antilles (LA; Grenada) from Woodland et al. (2002). Meimechites (high oxygen fugacity, low degree melts) from Mungall et al. (2006), high-F (melt fraction) melts from Momme et al. (2002, 2003), Puchtel et al. (2004), Dale et al. (2009b). (For interpretation to colours in this figure, the reader is referred to the web version of this paper.)

Lavas erupted at the MTJ have HSE abundances and ratios that are indistinguishable from MORB. In contrast, both arc and FSC samples are characterised by high PPGE concentrations and low IPGE abundances, relative to other moderate and high degree melts such as Mg-rich MORB and plume-related picrite-basalt suites (Fig. 6) and have correspondingly high PPGE/IPGE ratios (Figs. 4, 9, and 11). Previous PGE data from arc systems also show high primary PPGE/IPGE ratios (Woodland et al., 2002).

Southern FSC samples, and particularly central arc samples, typically have $\mathrm{Ir} / \mathrm{Ru}>1$. The presence of high $\mathrm{Ir} / \mathrm{Ru}$ in some of the most primitive samples from the most depleted source mantle suggests that it is probably a primary melt feature. Most MORB have chondrite-normalised $\mathrm{Ir} / \mathrm{Ru}$ $<1$, but higher ratios are observed in about a quarter of MORB (Bezos et al., 2005), and in one sample from the MTJ. The following sections discuss the various factors which may affect HSE abundances and relative proportions in Tongan magmas.

\subsection{Mantle source controls on behaviour of HSEs in primitive arc and FSC melts}

\subsubsection{Prior melt depletion and its effect on residual sulphide}

Lavas from the Mangatolu Triple Junction (MTJ) are indistinguishable from MORB in terms of HSE patterns, consistent with the passive upwelling of moderately 
Table 2

Parameters for melting and fractional crystallisation models.

\begin{tabular}{|c|c|c|c|c|c|}
\hline & $\mathrm{Ir}$ & $\mathrm{Ru}$ & $\mathrm{Pt}$ & $\mathrm{Pd}$ & $\mathrm{Cu}$ \\
\hline Depleted mantle concs. (ng/g) ${ }^{a}$ & 2.9 & 5.7 & 6.2 & 5.2 & - \\
\hline Primary melt composition (ng/g) & 0.5 & 0.3 & 10 & 15 & 8000 \\
\hline $\mathrm{D}$ sil/sil liq ${ }^{\mathrm{b}}$ & 2 & 2 & 0.008 & 0.01 & 0.01 \\
\hline D Al-spinel/sil liq ${ }^{c}$ & 20 & 20 & 0.02 & 0.02 & - \\
\hline D Cr-spinel/sil liq ${ }^{\mathrm{d}}$ & 100 & 400 & 0.01 & 0.01 & 0.01 \\
\hline D sul liq/sil liq & $130,000^{\mathrm{e}}$ & $50,000^{\mathrm{f}}$ & $35,000^{\mathrm{e}}$ & $35,000^{\mathrm{e}}$ & 1000 \\
\hline \multirow[t]{2}{*}{$\mathrm{D}$ mss/sul liq ${ }^{\mathrm{g}}$} & 5 & 10 & 0.05 & 0.012 & - \\
\hline & BAB melting & & Sub-arc melting & & \\
\hline Sulphur solubility ( $\mu \mathrm{g} / \mathrm{g})$ & $1000^{\mathrm{h}}$ & & $1500^{\mathrm{i}}$ & & \\
\hline Proportion of sulphide as mss & 0.5 & & 0.75 & & \\
\hline Sulphur concentration in DMM prior to melting & & $150 \mu \mathrm{g} / \mathrm{g}$ & & & \\
\hline Addition of $\mathrm{S}$ to sub-arc mantle by slab fluids & & $200 \mu \mathrm{g} / \mathrm{g}$ & & & \\
\hline
\end{tabular}

$\mathrm{D}_{\mathrm{mss} / \mathrm{sil} \mathrm{liq}}$ calculated from $\mathrm{D}_{\mathrm{mss} / \mathrm{sul} \mathrm{liq}}$ and $\mathrm{D}_{\text {sul liq/sil liq. }}$ Al-spinel used for 1st stage melting, Cr-spinel for sub-arc melting of depleted mantle.

a Salters and Stracke (2004).

b Brenan et al. (2003, 2005).

c Capobianco and Drake (1990).

d Park et al. (2012) and Refs. therein.

e Peach et al. (1990).

f Andrews and Brenan (2002).

g Mungall et al. (2005).

h Mavrogenes and O’Neill (1999).

i Jugo et al. (2010).

depleted mantle in this region. This is also reflected in their relatively flat REE patterns, with the exception of slight LREE enrichment from a slab fluid component (Keller et al., 2008).

In contrast, many arc and FSC lavas have boninitic affinities, indicating a highly depleted source (e.g. Crawford et al., 1989), and this is reflected in their distinct HSE patterns. For these magmas, recent models of melt depletion based on lithophile elements indicate the requirement for two stages of melting of a depleted MORB mantle (DMM) source - the first beneath the backarc spreading centre and the second beneath the arc (Caulfield et al., 2008; Cooper et al., 2010). While both models suggest high degrees of sub-arc melting ( $15-35 \%$ and $\sim 25 \%$ for Caulfield and Cooper, respectively), the melt fraction estimated for the first episode varies considerably between $1 \%$ and $10 \%$. Nevertheless, both models have aggregate melting fractions of DMM of $25 \%$ or greater. This value is close to or above estimates of the melt fraction required to remove monosulphide solid solution (mss) as a residual phase (e.g. Barnes et al., 1985; Pearson et al., 2004), even at the lower $\mathrm{fO}_{2}$ of typical mantle. Modelling of sulphur contents indicates that sulphide is unlikely to be a residual phase within the mantle, due to prior melt depletion (see below and Table 2 for parameters), unless there is a substantial flux of $\mathrm{S}$ from the slab $(>200 \mu \mathrm{g} / \mathrm{g})$. The sulphide undersaturated nature of the arc and FSC magmas is consistent with this result (see Figs. 6 and 7).

The effect of prior melt depletion on the HSE content of the $2^{\text {nd }}$-stage (arc) melts can be investigated using $\mathrm{Pt} / \mathrm{Ru}_{10}$ as a function of $\mathrm{Nb} / \mathrm{Yb}_{10}$ for each location, both estimated at $10 \mathrm{wt} . \% \mathrm{MgO}$ by using their co-variance with $\mathrm{MgO}$. In theory, $\mathrm{Nb} / \mathrm{Yb}$ is an indicator of melt depletion that has not been significantly altered by any slab fluid flux. Given the small number of samples from each location, and the sometimes variable $\mathrm{Pt} / \mathrm{Ru}$, this estimate carries significant uncertainty, but we believe it provides a useful comparative indicator. There is clear co-variance across the suite as a whole, and particularly within the FSC, with high Pt/ $\mathrm{Ru}_{10}$ at low $\mathrm{Nb} / \mathrm{Yb}_{10}$ (the most melt-depleted), and with depletion increasing from north to south (Fig. 12a). The high $\mathrm{Pt} / \mathrm{Ru}_{10}$ in Volcano $\mathrm{L}$ is at odds with its higher $\mathrm{Nb} /$ $\mathrm{Yb}_{10}$. This suggests either a greater effect of slab fluid on HSE behaviour here (compared with the FSC) or, more likely, the involvement of an additional sedimentary component imparting high $\mathrm{Nb} / \mathrm{Yb}$ (and high $\mathrm{Th} / \mathrm{Yb}$, Fig. 2) with a lesser effect on $\mathrm{Pt} / \mathrm{Ru}$. Extreme $\mathrm{Pt} / \mathrm{Ru}$ ratios are not always present in individual samples (Fig. 9), but when this ratio is closer to the MORB range, the $\mathrm{Cu} / \mathrm{PPGE}$ ratios are also most MORB-like (Fig. 7) and they have the least boninitic affinity (Fig. 2), again suggesting a link between mantle depletion and $\mathrm{Pt} / \mathrm{Ru}$ fractionation. The broad covariation of $\mathrm{Pt} / \mathrm{Ru}_{10}$ and $\mathrm{Nb} / \mathrm{Yb}_{10}$ therefore strongly suggests that mantle depletion, both prior to and concurrent with the melting which formed these lavas, exerts a strong control on inter-element HSE fractionation.

\subsubsection{Influence of the slab flux}

6.3.2.1. HSE flux from the slab. It has been previously recognised, in two subduction zones, that mantle wedge xenoliths can have variable enrichments in $\mathrm{Pt}$ and $\mathrm{Pd}$ (McInnes et al., 1999; Kepezhinskas et al., 2002). An abundance of Pt-rich alloy grains in alluvial deposits from suprasubduction zone ophiolites (Cabri et al., 1996; Brenker et al., 2003) may also reflect Pt enrichment of the mantle wedge. Dale et al. (2007, 2009a) found that Pt, Pd and Re 

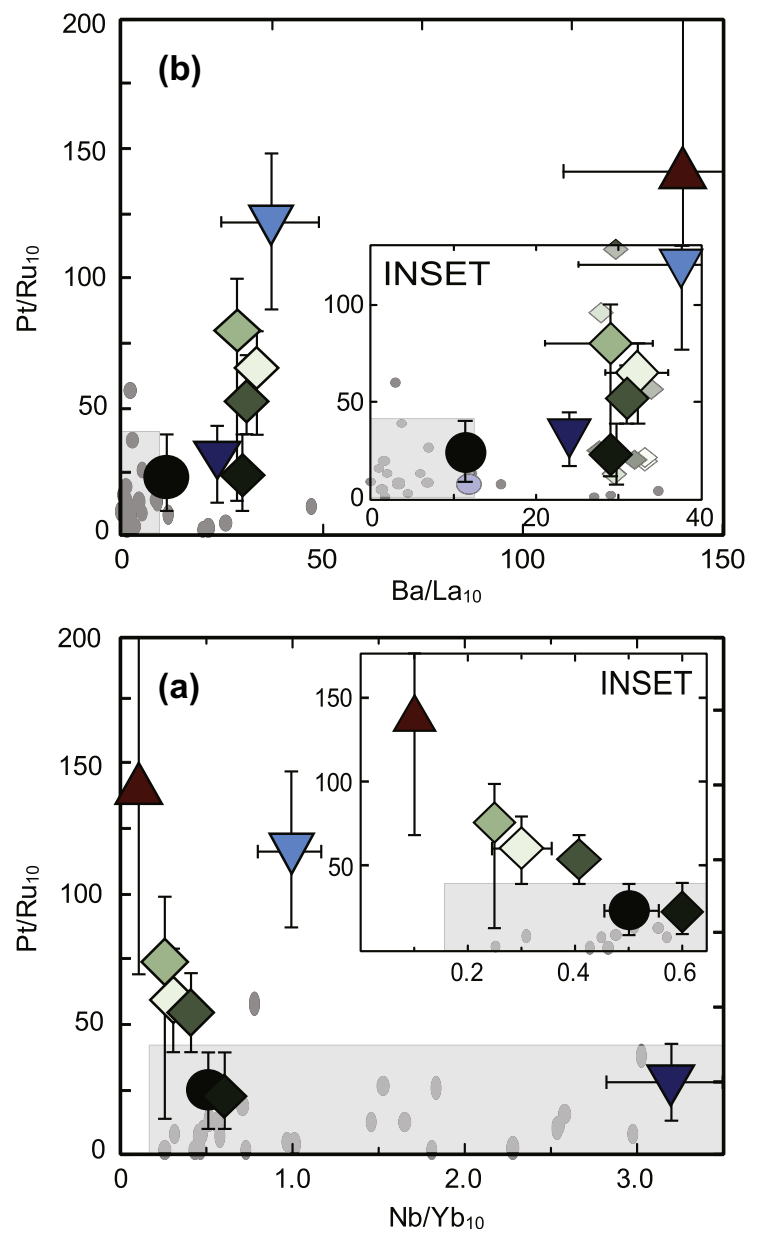

Fig. 12. Estimated average $\mathrm{Pt} / \mathrm{Ru}$ at $10 \mathrm{wt} . \% \mathrm{MgO}\left(\mathrm{Pt} / \mathrm{Ru}_{10}\right)$ as a function of $(b)$ estimated $\mathrm{Ba} / \mathrm{La}_{10}$, an indicator of elemental flux by slab fluid, and (a) estimated $\mathrm{Nb} / \mathrm{Yb}_{10}$, an indicator of degree of prior mantle depletion. MORB data (Bezos et al., 2005) is not corrected to 10 wt. $\%$ MgO. Symbols as previously: dark red triangle - Volcano A, mid-blue inverted triangle - L, dark blue inverted triangle $-\mathrm{O}$, black circle - MTJ, diamonds from light (south) to dark (north) - SFSC, CSFSC, CNFSC, NFSC. (For interpretation of the references to colour in this figure legend, the reader is referred to the web version of this article.)

are depleted in mafic oceanic crust metamorphosed under conditions akin to subduction zones, and thus inferred that these elements are transferred to the mantle wedge by slabderived fluids. Some Tongan lavas have Pt and Pd contents approximately twice as high as comparable $\mathrm{MgO}$ intraplate melts (e.g. Bennett et al., 2000; Momme et al., 2003; Ireland et al., 2009; Day et al., 2010). Whether enrichment in the mantle wedge can singularly account for such elevated $\mathrm{Pt}$ and $\mathrm{Pd}$ is doubtful considering the concentrations of these elements in the fluids and the mantle. Platinum and $\mathrm{Pd}$ are far more abundant in moderately depleted mantle (DMM: $6.2 \mathrm{ng} / \mathrm{g} \mathrm{Pt}, 5.2 \mathrm{ng} / \mathrm{g} \mathrm{Pd}$; Salters and Stracke, 2004) than in oceanic crust (MORB $\sim 0.4-0.5 \mathrm{ng} / \mathrm{g} \mathrm{Pt}$, $\sim 0.7-0.8 \mathrm{Pd})$. This means that very high fluid/rock ratios $(\sim 10)$ would be required in order to generate a twofold increase in Pt concentrations in the mantle (if assuming fluid/ rock ratio in slab equals 1 ; and $\mathrm{Pt}$ and $\mathrm{Pd}$ losses from the slab are $70 \%$ and $85 \%$, respectively (Dale et al., 2009a)). Only redistribution of PPGE within the mantle wedge (cf. Arculus and Powell, 1986, for lithophile elements) or possibly a significant flux from dehydrating serpentinite in the slab could generate such enrichments. However, as discussed below, the production of $\mathrm{Pt}-\mathrm{Pd}$-rich Tonga Arc magmas may not primarily require an enriched source and, moreover, the low IPGE concentrations of Tongan lavas at a given $\mathrm{MgO}$, relative to magmas from other tectonic settings, must require an alternative mechanism of generation.

6.3.2.2. Fluid-flux melting and oxygen fugacity. Fluid-fluxed melting occurs beneath the arc and FSC, while decompression melting is predominant in the back arc (Regelous et al., 2008; Caulfield, unpublished data). This may be critical for explaining the fractionation of the PPGE from IPGE in Tongan lavas. A fluid flux from the down-going slab will carry with it potential oxidising agents, elements that are present in variable oxidation states $(\mathrm{H}, \mathrm{S}, \mathrm{C}$, and $\mathrm{Fe})$, with the ability to modify the oxygen fugacity of sub-arc mantle (e.g. Mungall, 2002). The $\mathrm{fO}_{2}$ of the mantle is likely to be important for HSE behaviour during melting due to the effect that it has on sulphur. As $\mathrm{fO}_{2}$ increases, the proportion of sulphur present as sulphate also increases, reducing the amount of sulphide and increasing the solubility of $\mathrm{S}$ in the melt (from $\sim 1000 \mathrm{ppm}$ at FMQ-1, $\sim 1800$ at FMQ +1 , to $>1 \%$ at $>$ FMQ +2 ; Jugo, 2009; Jugo et al., 2010). This increases the likelihood of reaching sulphide-out in the mantle residue which, in the case of high degree melts, results in magmas with high, relatively unfractionated PGE abundances (e.g. Puchtel and Humayun, 2000; Momme et al., 2003) (Figs. 6, 9 and 11). Exhaustion of sulphide in the source due to elevated $\mathrm{fO}_{2}$, as opposed to high melt fraction, has been proposed for meimechites - low fraction melts from an oxidised source (FMQ $\sim+2.5)$ - which also possess high and unfractionated PGE abundances (Mungall et al., 2006) (Fig. 11). In contrast, the PGE abundances in the Tonga Arc either indicate that sulphide is still present in the source or that there is another phase(s) controlling PGE fractionation. We can infer from this that elevated oxygen fugacity is not solely responsible for the PGE fractionation observed. The presence of a fluid phase, however, and any attendant increase in oxygen fugacity, may influence the existence and proportion of monosulphide solid solution (mss) to sulphide liquid (see Mungall et al., 2006) potentially leading to PGE fractionation during partial melting (see residual mineralogy below).

If HSE fluxing or fluid-flux melting and oxidation state are key to the generation of high PPGE/IPGE in arc magmas, it might be expected that $\mathrm{Pt} / \mathrm{Ru}$ would co-vary with typical indicators of slab fluid flux such as $\mathrm{Ba} / \mathrm{La}$. In order to assess the primitive melt characteristics, $\mathrm{Pt} / \mathrm{Ru}$ and $\mathrm{Ba} /$ La have been estimated at 10 wt. $\% \mathrm{MgO}$ (e.g. Pt/Ru $\mathrm{Ru}_{10}$ ) for each location (Fig. 12b), by using the co-variance of these ratios with $\mathrm{MgO}$. There is broad co-variance of $\mathrm{Pt} /$ $\mathrm{Ru}_{10}$ and $\mathrm{Ba} / \mathrm{La}_{10}$ across the arc as a whole, although Volcano A lavas have much higher $\mathrm{Ba} / \mathrm{La}_{10}$ with only slightly higher $\mathrm{Pt} / \mathrm{Ru}_{10}$. In detail, the co-variation is poorer with 
little range in $\mathrm{Ba} / \mathrm{La}_{10}$ across the FSC accompanied by a fourfold variation in $\mathrm{Pt} / \mathrm{Ru}_{10}$. However, $\mathrm{Ba} / \mathrm{La}$ is not only an indicator of slab fluid flux, because this ratio can vary with degree of melt depletion. Thus, it is difficult to explain the broad co-variance of $\mathrm{Ba} / \mathrm{La}_{10}$ and $\mathrm{Pt} / \mathrm{Ru}_{10}$ by any one factor, with likely contributions from elevated oxygen fugacity (giving rise to higher sulphur solubility and the likelihood of sulphide exhaustion), prior depletion and possibly some Pt enrichment from the fluid.

In detail, the effect of fluid and $\mathrm{fO}_{2}$ on HSE behaviour is, as yet, untested due to the few available constraints on the stability, under mantle conditions, of HSE-rich platinumgroup minerals (PGM) which can control the HSE budget once sulphide is exhausted (e.g. Luguet et al., 2007). However, the addition of fluid to the wedge will markedly reduce the peridotite solidus - causing melting - while its effect on sulphide melting temperature (and PGM?) may be small (Naldrett, 1969; see following section). Thus, the arc HSE signature may principally depend on the low temperature of flux melting, inasmuch as mss or some PGM, have thermal limits of stability that may allow retention during low temperature melting (e.g. laurite: $1275^{\circ} \mathrm{C}$, Brenan and Andrews, 2001).

\subsubsection{Residual mineralogical control on PPGE/IPGE fractionation in melts}

In order to produce low primary $\mathrm{Ru}$ contents and high $\mathrm{Pt} / \mathrm{Ru}$ in melts, the residual mineralogy in the mantle must retain $\mathrm{Ru}$ (and the other IPGE). Phases which may contribute significantly to the PGE budget, and therefore have the potential to cause the observed fractionation, are: monosulphide solid solution (mss), sulphide liquid, olivine, spinel and platinum-group minerals (PGM).

6.3.3.1. Olivine. Available experimental data suggests that the distribution coefficients for IPGE between olivine and silicate melt ( $D^{\text {olivine/melt }} \sim 2$ ) are considerably higher than for PPGE $(\leqslant 0.01$, Brenan et al., 2003, 2005). While this means that residual olivine will generate PPGE/IPGE $>1$ in the melt, the difference in coefficients is not sufficient to produce fractionation of the magnitude seen in the Tonga Arc (max Pt/Ru of $\sim 12$ at $15 \%$ melt fraction, after $5 \%$ prior depletion during backarc melting - see Table 2 for modelling parameters - compared to $\mathrm{Pt} / \mathrm{Ru} 20$ - 150 for primitive Tonga samples). Moreover, the absolute IPGE concentrations in the melt would be 1-2 orders of magnitude too high without the buffering influence of residual sulphide (Fig. 13).

6.3.3.2. Sulphides: monosulphide solid solution (mss) and sulphide liquid. Base-metal sulphides in the mantle typically consist of $\mathrm{Fe}-\mathrm{Ni}$-rich mss and $\mathrm{Cu}-\mathrm{Ni}$-rich intermediate solid solution (iss), which are intergrown on a sub-grain scale (Luguet et al., 2004; Bockrath et al., 2004a). Upon partial melting, base-metal sulphides melt incongruently giving rise to $\mathrm{Cu}-\mathrm{Ni}$-rich sulphide liquid while mss becomes more $\mathrm{Fe}$ rich as melting progresses (e.g. Bockrath et al., 2004a). The partitioning behaviour of the HSE between mss and sulphide liquid varies considerably, from compatible to highly incompatible, in the order: $\mathrm{Os} \sim \mathrm{Ir} \sim \mathrm{Ru}>>\mathrm{Pt}>\mathrm{Pd}>\mathrm{Re}$

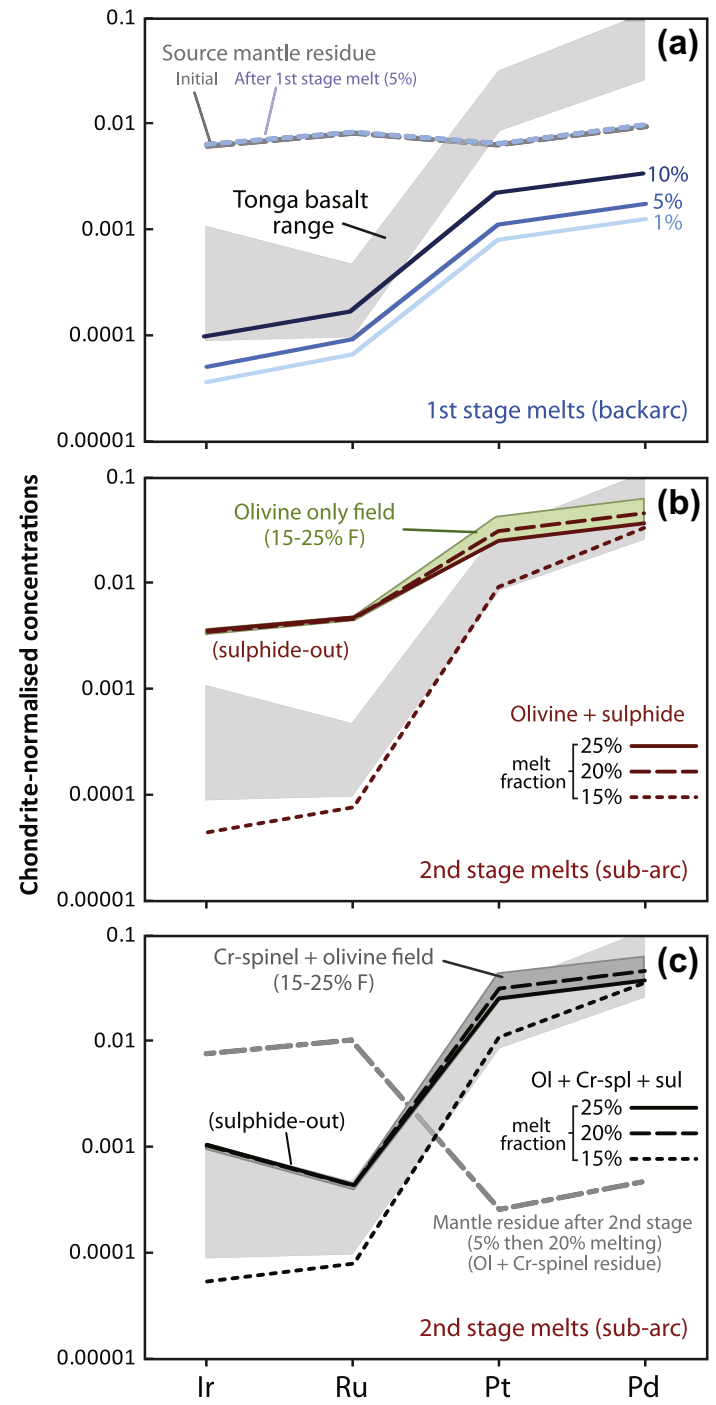

Fig. 13. Modelling of PGE concentrations in melts generated in a two-stage melting regime: (a) first stage melting beneath the backarc; (b) and (c) second stage, sub-arc melts, with four different residual mantle mineralogies (labelled). The initial source mantle, prior to backarc melting (DMM composition, Salters and Stracke, 2004), and the residues after the first stage and second stages of melting are shown. First stage melting is required to explain lithophile elements (Caulfield et al., 2008; Cooper et al., 2010) and also depletes the mantle in sulphur, while slightly increasing HSE concentrations. Second stage melting $(\geqslant 20 \%)$ leaves a residue of Olivine $+\mathrm{Cr}$ spinel \pm PGM, without sulphide; hence sulphide ceases to be a controlling phase even in models including sulphide. Residual mantle containing only olivine or olivine $+\mathrm{Cr}$-spinel produces melts that have a limited HSE range for 15-25\% melting and hence only fields are shown. Moderate degree $(\sim 5 \%)$ melting in the back arc is required to produce both the PGE patterns and absolute concentrations in the arc melts. Residual mantle mss, Cr-spinel and PGM are all capable of producing large PPGE/IPGE fractionation, but only the latter two generate positive $\mathrm{Ir} / \mathrm{Ru}$ anomalies in the melts. Moreover, retention of Cr-spinel and PGM in the source does not require a specific and limited window of melting degree, which is not the case for residual sulphide. Sulphide is, however, probably required to account for HSE concentrations at the lower end of the Tongan range. For parameters see Table 2. (For interpretation to colours in this figure, the reader is referred to the web version of this paper.) 
from $\mathrm{D}^{\mathrm{mss} / \mathrm{sul} \mathrm{liq}} \sim 10$ for $\mathrm{Ru}$ to 0.05 for $\mathrm{Re}$ ( $\mathrm{Li}$ et al., 1996; Mungall et al., 2005). This means that by exhausting sulphide liquid in the mantle source, but not mss, it is possible to greatly fractionate between the IPGE and PPGE.

Quantitative modelling of two-stage batch melting of mantle (backarc and then arc), involving solid silicate, silicate melt, mss and sulphide liquid, reveals that retention of mss, but not sulphide liquid, broadly produces the observed PPGE/IPGE fractionation in Tongan Arc/FSC melts, using a certain, non-unique, set of parameters (Fig. 13, Table 2 and caption). The variables in this model are numerous, with some poorly constrained: $\mathrm{S}$ content of backarc mantle prior to the first stage of melting, solubility of sulphur in both stages of melting (which depends on $\mathrm{T}, \mathrm{P}$, melt composition and, in the latter case, elevated oxygen fugacity, which will increase solubility (e.g. Jugo, 2009)), melt fraction of first and second stage melting, addition of $\mathrm{S}$ to the mantle wedge by slab fluid (for which there is little constraint). In addition, phase equilibria in the system $\mathrm{Fe}-$ $\mathrm{Ni}-\mathrm{Cu}-\mathrm{S}$ are not well enough constrained to predict the relative contribution of mss and sulphide liquid to a melt at various conditions $\left(\mathrm{T}, \mathrm{P}\right.$, composition, $\left.\mathrm{fO}_{2}\right)$, and so this parameter has been adjusted to provide the best fit (c.f. Mungall et al., 2006; Karrei, 2008). Due to depletion of S during the backarc stage of melting $(\mathrm{F}=5 \%)$, a significant, and probably unrealistic, addition of $\mathrm{S}(>200 \mu \mathrm{g} / \mathrm{g})$ to the sub-arc mantle is required to avoid complete sulphide consumption during 20\% sub-arc partial melting (aggregate melting of $25 \%$ ). If higher degrees of melting occurred, the flux of $\mathrm{S}$ from the slab would have to be greater still. The elevated $\mathrm{Ir} / \mathrm{Ru}$, which is likely to be, at least in part, a primary melt effect (see earlier) is not reproduced by this model (Fig. 13).

Typical mantle potential temperature $\left(\sim 1310^{\circ} \mathrm{C}\right)$ is greater than the liquidus of mss at $1 \mathrm{GPa}\left(\sim 1275^{\circ} \mathrm{C}\right.$, Eggler and Lorand, 1993; Bockrath et al., 2004a), meaning that sulphide will not melt in the divariant mss-sulphide liquid field (Mungall et al., 2006), i.e. mss-sulphide liquid partitioning is not applicable. The addition of water, however, lowers the peridotite solidus, whilst probably not having a noticeable effect on sulphide solidi (cf. pyrrhotite, Naldrett, 1969), meaning both sulphide components can be present during melting, if the ambient mantle temperature is cooler as a result of subduction dynamics (melt inclusion equilibration temperatures indicate a minimum of $\sim 1200^{\circ} \mathrm{C}$ for Volcano A melts; Cooper et al., 2010). But Mungall et al. (2006) recognised that at an undetermined $\mathrm{fO}_{2}$ higher than FMQ, sulphide will largely melt in the spinel-sulphide liquid field, rather than the mss-sulphide liquid field, after initial rapid consumption of mss. This, combined with increased S solubility (Jugo, 2009), means that retention of interstitial mss seems unlikely in the oxidised Tongan Arc mantle (Keller et al., 2008).

The retention of mss included within silicate crystals (particularly olivine) may be a possible mechanism to retain mss in the mantle residue even at mantle temperatures and degrees of melting that are sufficiently high to completely consume all sulphide. However, the very large degrees of melting proposed for the Tonga Arc (15-35\%) make this an unlikely scenario as many intra-granular sulphides would become exposed to the melt as their silicate host melts. In addition, an equivalent effect of retention of intra-granular mss is not observed in other high-degree mantle melts (c.f. Puchtel and Humayun, 2000; Momme et al., 2003).

In summary, while Tongan HSE fractionation can be modelled non-uniquely using batch melting of silicate, sulphide liquid and mss, it seems unlikely that sufficient mss will have been retained given the depleted nature of the sub-arc mantle, the aggregate degree of partial melting and the elevated oxygen fugacity. Addition of $\mathrm{S}$ by slab fluids may allow sulphide to remain, but such addition may increase $\mathrm{fO}_{2}$ to the sulphide-sulphur oxide buffer $(\sim+2$ FMQ) (Mungall, 2002), at which point a significant proportion of the sulphur will be present as sulphate, potentially increasing S solubility to $\sim 4500 \mu \mathrm{g} / \mathrm{g}$ (Jugo, 2009).

6.3.3.3. Spinel. Spinel is thought to be a significant host of $\mathrm{Ru}$, and possibly the IPGE in general, but with a $\mathrm{D}^{\text {spinel/melt }}$ of 20 (Capobianco and Drake, 1990), extreme PPGE/IPGE fractionation will not be observed due to a low modal abundance of spinel in the residue (even $20 \%$ spinel $+80 \%$ olivine would produce $\mathrm{Pt} / \mathrm{Ru}$ of $<18$ in the melt for $\geqslant 15 \%$ melting of a source previously depleted by $5 \%$ melting in the backarc). However, recent work indicates that compatibility of $\mathrm{Ru}$ in $\mathrm{Cr}$-rich spinel increases markedly with oxygen fugacity, to $\mathrm{D}^{\text {spinel/melt }} \sim 500$ at an $\mathrm{fO}_{2}$ of $\sim 0.5 \mathrm{FMQ}$ (Puchtel and Humayun, 2001; Park et al., 2012). Quantitative modelling illustrates that $\mathrm{Cr}$-spinel can therefore potentially produce the observed PGE fractionation in Tongan lavas (Fig. 13), including the fractionation of $\mathrm{Ru}$ from $\mathrm{Ir}$ due to the lesser compatibility of the latter in Cr-spinel. Moreover, platinum-group minerals (PGM) commonly nucleate on spinel surfaces, further increasing the bulk capacity for $\mathrm{Cr}$-spinel-rich rocks to host $\mathrm{Ru}$ and the other IPGE including Ir which forms surficial micro-nuggets (Locmelis et al., 2011). In practice, it is difficult to distinguish between mantle retention of IPGE by $\mathrm{Cr}$-spinel and very early $\mathrm{Cr}$-spinel fractionation, but chromitites and dunites, which contain Cr-spinel and associated PGM are known to form in sub-arc ophiolitic mantle as a result of melt depletion and melt-peridotite interaction (Garuti et al., 1999; Gonzalez-Jimenez et al., 2011). These rocks are enriched in IPGE over PPGE, a signature that is broadly equivalent to the modelled mantle residue after the $2^{\text {nd }}$ stage of melting (Fig. 13).

6.3.3.4. Platinum-group minerals (PGM). Platinum-group elements can form discrete metal, alloy (PGA) or sulphide phases in certain geological circumstances, namely when the limit of PGE solubility is reached or when melt depletion of base-metal sulphide is complete (Luguet et al., 2007). Such exhaustion of sulphide in the Tongan sub-arc mantle is likely (see above). Osmium, $\mathrm{Ir}, \mathrm{Ru}$ and $\mathrm{Pt}$ are the most prone to forming PGM, with Pt tending to form alloys with $\mathrm{Fe}$ and/or Ir, and the IPGE typically forming Os-Ir-Ru alloys or Ru-Os-(Ir)-rich sulphides (laurite-erlichmanite) (Cabri et al., 1996; Luguet et al., 2007; Lorand et al., 2010). The high Pt concentrations in Tongan melts preclude $\mathrm{Pt}$ alloys as a major residual phase in the 
sub-arc mantle. However, IPGE alloys and laurite, if present, will retain $\mathrm{Os}, \mathrm{Ir}$ and $\mathrm{Ru}$ in the residue, giving rise to extremely high $\mathrm{Pt} / \mathrm{Ru}$ ratios in the melts also recently proposed by Mungall et al. (2011). Given the concentrations of PGE at tens of percent-level in PGM, only about 20 $5 \mu \mathrm{m}$-diameter spherical PGM $\left(65 \mu^{3}\right)$ within $1 \mathrm{~g}$ of rock would be required to host half $(\sim 3.5 \mathrm{ng} / \mathrm{g})$ of the retained $\mathrm{Ru}$ budget - a number of the same order as found in some depleted harzburgites (Luguet et al., 2007). Qualitatively, laurite typically contains more $\mathrm{Ru}$ and $\mathrm{Os}$ than $\mathrm{Ir}$, possibly explaining elevated $\mathrm{Ir} / \mathrm{Ru}$ in Tongan melts. In addition, laurite (and PGM in general) is more refractory than base-metal sulphide (Brenan and Andrews, 2001; Bockrath et al., 2004b) and hence is more likely to be retained during melting. Laurite-rich PGM assemblages have been observed directly in highly depleted harzburgites and lherzolites (refertilised harzburgites) of the Lherz massif (Luguet et al., 2007; Lorand et al., 2010), and in Cr-spinel rich rocks from ophiolites (Garuti et al., 1999; Gonzalez-Jimenez et al., 2011). Speculatively, the transition from laurite to Ru-alloy stability with increasing temperature (Brenan and Andrews, 2001) may account for the low Ru, but higher Os, in the higher temperature picritic arc melts of the Lesser Antilles (Woodland et al., 2002) (Fig. 11).

In summary, despite high degrees of melt depletion, the IPGE must be retained in the mantle due to $\mathrm{Cr}$-spinel and PGM stability, and/or residual mss. The likelihood of complete sulphide consumption in the source makes PGMbearing Cr-spinel rich rocks our preferred host of residual IPGE. The apparent link between mantle depletion and HSE fractionation observed in Tongan rocks (see $\mathrm{Nb}$ / $\mathrm{Yb}_{10}$ vs. Pt/Ru $\mathrm{Ru}_{10}$, Fig. 12a), may thus be explained by an increase in $\mathrm{Cr}$ content of spinel as a result of depletion, and concomitant sulphide exhaustion and formation of PGM.

\subsection{Behaviour of osmium in the slab flux and wider implications of HSE fractionation in subduction zones}

Osmium isotopes have been central to many debates about recycled crust and core contributions to OIB (e.g. Reisberg et al., 1993; Walker et al., 1995; Widom, 1997; Brandon et al., 1998; Dale et al., 2007; Luguet et al., 2008b; Day et al., 2010). However, it has become increasingly apparent that the Os isotopic signature of mantle melts may not accurately reflect the bulk isotopic signature of their source. This is due to preferential sampling of radiogenic components within the source by small degree melts, incorporation of interstitial sulphide during ascent (Sen et al., 2011) and/or shallow-level contamination by crustal assimilation, seawater or hydrothermal fluids (Widom and Shirey, 1996; Gannoun et al., 2007). These effects can be seen in the Os isotope data for Tongan samples (Fig. 8), with the radiogenic input most marked in samples with less than $0.02 \mathrm{ng} / \mathrm{g}$ Os, suggesting crustal assimilation and preferential sampling of subduction-derived radiogenic components are both potential contributors of radiogenic Os in the Tongan suite. Most Tongan samples broadly define a single trend in Os- ${ }^{187} \mathrm{Os} /{ }^{188}$ Os space (Fig. 8), which might indicate a source control, rather than alteration or crustal contamination, given that they sample a variety of settings and magma systems. However, in detail this is difficult to assess because measured, rather than initial ratios, are presented due to the lack of available age constraints for these rocks. Thus, although the fresh nature of the suite is indicative of a young age, there will be a small, unquantifiable, but not necessarily insignificant element of ingrowth of ${ }^{187}$ Os (cf. MORB; Gannoun et al., 2004). In general, though, the fact that there is co-variation of Os isotopes with Os content in single samples (Fig. S2) rules out a source control alone.

Regardless of the explanation for radiogenic Os in lowOs samples, when Tongan magmas have $>0.02 \mathrm{ng} / \mathrm{g}$ Os their Os isotope ratios are generally indistinguishable from MORB, a feature also seen in other arc lavas (Woodland et al., 2002; Dreher et al., 2005). The isochron or mixing line for Volcano A replicates (Fig. S2) gives an initial or uncontaminated ${ }^{187} \mathrm{Os} /{ }^{188} \mathrm{Os}$ of 0.128 to 0.131 (the lowest value measured), consistent with a minimally enriched mantle source. Thus, it seems likely that any flux of radiogenic Os into the Tongan sub-arc mantle is largely insignificant compared to the concentration of Os present in the mantle prior to metasomatism. However, without knowing the Os isotope composition of the pre-existing arc-mantle, which potentially could have been unradiogenic compared to 'typical' upper mantle (e.g. Parkinson et al., 1998; Pearson et al., 2007), addition of radiogenic Os to the mantle source of some magmas cannot be ruled out. This is a potential problem for all Os studies of subduction zone rocks (see Woodhead and Brauns, 2004). Boninitic Cr-spinels from the Bonin Islands have lower ${ }^{187} \mathrm{Os} /{ }^{188}$ Os $(0.1230-0.1242$; Suzuki et al., 2011) than any Tongan magma, and thus some degree of enrichment in radiogenic Os in the Tongan mantle is possible.

Several studies have now identified that significant fractionation of $\mathrm{Pt}, \mathrm{Re}$ and Os occurs in subduction zones, both through analysis of sub-arc mantle xenoliths and high-pressure metamorphic mafic rocks (McInnes et al., 1999; Kepezhinskas et al., 2002; Dale et al., 2009a). This study further demonstrates that $\mathrm{Pt}$ and $\mathrm{Re}$ fractionation from Os is a feature of subduction zones. It is not clear, however, to what extent the preferential partitioning of $\mathrm{Pt}$ (and $\mathrm{Re}$ ) into arc magmas reduces the potentially elevated $\mathrm{Pt} / \mathrm{Os}$ and $\mathrm{Re} / \mathrm{Os}$ of the mantle wedge. For this reason quantitative modelling of the Pt-Re-Os isotopic system in subduction zones has not been undertaken at this time. However, we draw attention to the fact that significant fractionation of Re and Pt from Os undoubtedly occurs in arc environments, with the potential to generate coupled enrichments of ${ }^{186}$ Os and ${ }^{187}$ Os with time (c.f. Luguet et al., 2008b).

The production of primitive high $\mathrm{Pt} / \mathrm{Ru}$ and $\mathrm{Ir} / \mathrm{Ru}$ magmas must leave mantle residues with supra-chondritic $\mathrm{Ru} /$ Ir, probably due to the presence of Ru-rich PGM. If these residues are refertilised through metasomatism, it is likely that the suprachondritic $\mathrm{Ru} / \mathrm{Ir}$ will remain. This may have implications for the estimation of HSE abundances in the primitive upper mantle (PUM), by means of comparing HSEs and Ir across a range of fertility (cf. Becker et al., 2006). Indeed, the presence of Ru-rich PGM in mantle residues and apparently fertile mantle rocks has recently been highlighted as a potential explanation for the apparently 
supra-chondritic Ru concentration of the PUM (Luguet et al., 2007; Lorand et al., 2010).

\section{CONCLUSIONS}

Mafic arc and recent proximal backarc lavas (Fonualei Spreading Centre) from the Tonga Arc system possess extremely elevated PPGE/IPGE ratios, amongst the highest reported in terrestrial magmas - a feature that is inherited from the source. Although Pt and Pd enrichment in the sub-arc mantle has been observed and inferred (McInnes et al., 1999; Dale et al., 2009a), a slab fluid flux seems an implausible mechanism by which to generate the necessary PPGE enrichment due to the order-of-magnitude higher PPGE concentrations in the mantle than in mafic crust. Such metasomatism also cannot account for the low IPGE contents. Instead, the fractionation likely results from a combination of prior source melt depletion, the low temperature of Tonga Arc flux-melting, and possibly elevated oxygen fugacity $(+0.5 \mathrm{FMQ}$, Keller et al., 2008). Given prior melt depletion, the high degree of melting ( $\sim 25 \%$ combined) and the elevated $\mathrm{fO}_{2}$, it is likely that sulphide has been completely consumed in the mantle residue. Such sulphide exhaustion would typically give rise to high concentrations of all HSEs, but with some dilution of HSEs at melt fractions beyond sulphide-out. Thus, the retention of IPGE in the Tongan sub-arc mantle suggests either the preservation of monosulphide solid solution (mss) due to addition of slab-derived S to the mantle wedge (Li et al., 1996; Mungall et al., 2005; Karrei, 2008) or the presence of Cr-spinel and/ or platinum-group minerals (PGM). Our preferred model is one in which residual PGM, particularly laurite ( $\mathrm{Ru}-\mathrm{Os}-$ (Ir) sulphide) or IPGE alloys, are present together with Cr-spinel (found in depleted ophiolitic mantle sections; e.g. Garuti et al., 1999), producing the exceptionally high PPGE/IPGE, and also explaining the high $\mathrm{Ir} / \mathrm{Ru}$ in Tongan melts.

All the PGE in the Tonga magmas behave less compatibly during magma evolution than is the case in MORB. Copper incompatibility indicates that the melts were sulphide undersaturated above 3-5 wt.\% $\mathrm{MgO}$, thus accounting for the lower bulk compatibility of all PGE. We propose that the significantly higher compatibility of the IPGE than PPGE during melt evolution is due to incorporation into silicate and $\mathrm{Cr}$-spinel. Palladium concentrations are affected by syn-eruptional degassing, even at water depths of at least $2000 \mathrm{mbsl}$, with up to $50 \%$ being lost. Volatile loss of Re is evident in the shallowly erupted arc volcanics, but systematic $\mathrm{Re}$ variation with $\mathrm{MgO}$ and $\mathrm{Yb}$ in the FSC indicates that source and crystallisation effects dominate.

Osmium isotopes co-vary negatively with Os abundance and thus appear to be strongly affected by shallow level contamination. However, the most Os-rich samples have ${ }^{187} \mathrm{Os} /{ }^{188} \mathrm{Os}$ ratios $(0.126-0.132)$ indistinguishable from the MORB range, suggesting a minor or insignificant flux of Os from the slab. Sub-arc mantle melting and slab fluid element fluxes both potentially cause significant fractionation of Pt and Re from Os (this study and Dale et al., 2009a, respectively). Although sub-arc melting may negate the effect of the slab fluid flux, arc environments are undoubtedly an environment where significant fractionation of Re and Pt from Os occurs.

\section{ACKNOWLEDGEMENTS}

We thank the Captain, officers, technical and scientific crew of the R/V Southern Surveyor who took part in Cruise NoToVE to the Northeast Lau Basin and Tonga Arc in October-November 2004. This research was supported by grant NER/C51902X/1 from the Natural Environment Research Council. We are grateful to A. Luguet for comments which improved an earlier version of the manuscript. M. Bizimis, two anonymous reviewers and R.J. Walker are thanked for their careful constructive reviews and editorial handling.

\section{APPENDIX A. SUPPLEMENTARY DATA}

Supplementary data associated with this article can be found, in the online version, at http://dx.doi.org/10.1016/ j.gca.2012.03.025.

\section{REFERENCES}

Alard O., Griffin W. L., Lorand J. P., Jackson S. E. and O'Reilly S. Y. (2000) Non-chondritic distribution of the highly siderophile elements in mantle sulphides. Nature 407, 891-894.

Andrews D. R. A. and Brenan J. M. (2002) The solubility of ruthenium in sulfide liquid: implications for platinum group mineral stability and sulfide melt-silicate melt partitioning. Chem. Geol. 192, 163-181.

Arculus R. J. and Powell R. (1986) Source component mixing in the regions of arc magma generation. J. Geophys. Res.-Solid Earth Planets 91, 5913-5926.

Barnes S.-J., Naldrett A. J. and Gorton M. P. (1985) The origin of the fractionation of platinum-group elements in terrestrial magmas. Chem. Geol. 53, 303-323.

Barnes S. J. and Fiorentini M. L. (2008) Iridium, ruthenium and rhodium in komatiites: evidence for iridium alloy saturation. Chem. Geol. 257, 44-58.

Barnes S. J. and Liu W. (2012) Pt and Pd mobility in hydrothermal fluids: evidence from komatiites and from thermodynamic modelling. Ore Geol. Rev. 44, 49-58.

Becker H. (2000) Re-Os fractionation in eclogites and blueschists and the implications for recycling of oceanic crust into the mantle. Earth Planet. Sci. Lett. 177, 287-300.

Becker H., Horan M. F., Walker R. J., Gao S., Lorand J. P. and Rudnick R. L. (2006) Highly siderophile element composition of the Earth's primitive upper mantle: constraints from new data on peridotite massifs and xenoliths. Geochim. Cosmochim. Acta 70, 4528-4550.

Bennett V. C., Norman M. D. and Garcia M. O. (2000) Rhenium and platinum group element abundances correlated with mantle source components in Hawaiian picrites: sulphides in the plume. Earth Planet. Sci. Lett. 183, 513-526.

Bezos A., Lorand J. P., Humler E. and Gros M. (2005) Platinumgroup element systematics in mid-oceanic ridge basaltic glasses from the Pacific, Atlantic, and Indian Oceans. Geochim. Cosmochim. Acta 69, 2613-2627.

Birck J. L., Barman M. R. and Capmas F. (1997) Re-Os isotopic measurements at the femtomole level in natural samples. Geostand. Newsl. 20, 19-27.

Bockrath C., Ballhaus C. and Holzheid A. (2004a) Fractionation of the platinum-group elements during mantle melting. Science 305, 1951-1953. 
Bockrath C., Ballhaus C. and Holzheid A. (2004b) Stabilities of laurite RuS2 and monosulfide liquid solution at magmatic temperature. Chem. Geol. 208, 265-271.

Botcharnikov R. E., Linnen R. L., Wilke M., Holtz F., Jugo P. J. and Berndt J. (2011) High gold concentrations in sulphidebearing magma under oxidizing conditions. Nat. Geosci. 4, 112115.

Brandon A. D., Creaser R. A., Shirey S. B. and Carlson R. W. (1996) Osmium recycling in subduction zones. Science 272, 861864.

Brandon A. D., Walker R. J., Morgan J. W., Norman M. D. and Prichard H. M. (1998) Coupled ${ }^{186} \mathrm{Os}$ and ${ }^{187} \mathrm{Os}$ evidence for core-mantle interaction. Science 280, 1570-1573.

Brenan J. M. and Andrews D. (2001) High-temperature stability of laurite and $\mathrm{Ru}-\mathrm{Os}-\mathrm{Ir}$ alloy and their role in PGE fractionation in mafic magmas. Can. Mineral. 39, 341-360.

Brenan J. M., McDonough W. F. and Dalpe C. (2003) Experimental constraints on the partitioning of rhenium and some platinum-group elements between olivine and silicate melt. Earth Planet. Sci. Lett. 212, 135-150.

Brenan J. M., McDonough W. F. and Ash R. (2005) An experimental study of the solubility and partitioning of iridium, osmium and gold between olivine and silicate melt. Earth Planet. Sci. Lett. 237, 855-872.

Brenan J. M. (2008) Re-Os fractionation by sulfide melt-silicate melt partitioning: a new spin. Chem. Geol. 248, 140-165.

Brenker F. E., Meibom A. and Frei R. (2003) On the formation of peridotite-derived Os-rich PGE alloys. Am. Mineral. 88, 17311740.

Burton K. W., Schiano P., Birck J.-L., Allegre C. J., Rehkämper M., Halliday A. N. and Dawson J. B. (2000) The distribution and behaviour of rhenium and osmium amongst mantle minerals and the age of the lithospheric mantle beneath Tanzania. Earth Planet. Sci. Lett. 183, 93-106.

Burton K. W., Gannoun A., Birck J.-L., Allegre C. J., Schiano P., Clocchiatti R. and Alard O. (2002) The compatibility of rhenium and osmium in natural olivine and their behaviour during mantle melting and basalt genesis. Earth Planet. Sci. Lett. 198, 63-76.

Cabri L. J., Harris D. C. and Weiser T. W. (1996) Mineralogy and distribution of platinum-group mineral (PGM) placer deposits of the world. Explor. Min. Geol. 5, 73-167.

Capobianco C. J. and Drake M. J. (1990) Partitioning of ruthenium, rhodium, and palladium between spinel and silicate melt and implications for platinum group element fractionation trends. Geochim. Cosmochim. Acta 54, 869-874.

Carroll M. R. and Webster J. D. (1994) Solubilities of sulphur, noble-gases, nitrogen, chlorine, and fluorine in magmas. Volatiles Magmas, 231-279.

Caulfield J. T., Turner S. P., Dosseto A., Pearson N. J. and Beier C. (2008) Source depletion and extent of melting in the Tongan sub-arc mantle. Earth Planet. Sci. Lett. 273, 279-288.

Cohen A. S. and Waters F. G. (1996) Separation of osmium from geological materials by solvent extraction for analysis by thermal ionisation mass spectrometry. Anal. Chim. Acta 332, 269-275.

Cooper L. B., Plank T., Arculus R. J., Hauri E. H., Hall P. S. and Parman S. W. (2010) High-Ca boninites from the active Tonga Arc. J. Geophys. Res.-Solid Earth 115, B10206.

Crawford A. J., Falloon T. J. and Green D. H. (1989) Classification, petrogenesis and tectonic setting of boninites. In Boninites and Related Rocks (ed. A. J. Crawford). Unwin Hyman, London, pp. 1-49.

Dale, C.W., 2005. Recycling Oceanic Crust: Isotopic and Elemental Constraints From a High Pressure Terrain, Dept of Earth Sciences PhD Thesis, Open University, UK.
Dale C. W., Gannoun A., Burton K. W., Argles T. W. and Parkinson I. J. (2007) Rhenium-osmium isotope and elemental behaviour during subduction of oceanic crust and the implications for mantle recycling. Earth Planet. Sci. Lett. 253, 211-225.

Dale C. W., Luguet A., Macpherson C. G., Pearson D. G. and Hickey-Vargas R. (2008) Extreme platinum-group element fractionation and variable Os isotope compositions in Philippine Sea Plate basalts: tracing mantle source heterogeneity. Chem. Geol. 248, 213-238.

Dale C. W., Burton K. W., Pearson D. G., Gannoun A., Alard O., Argles T. W. and Parkinson I. J. (2009a) Highly siderophile element behaviour accompanying subduction of oceanic crust: whole rock and mineral-scale insights from a high-pressure terrain. Geochim. Cosmochim. Acta 73, 1394-1416.

Dale C. W., Pearson D. G., Starkey N. A., Stuart F. M., Ellam R. M., Larsen L. M., Fitton J. G. and Macpherson C. G. (2009b) Osmium isotopes in Baffin Island and West Greenland picrites: implications for the Os-187/Os-188 composition of the convecting mantle and the nature of high $\mathrm{He}-3 / \mathrm{He}-4$ mantle. Earth Planet. Sci. Lett. 278, 267-277.

Day J. M. D., Pearson D. G., Macpherson C. G., Lowry D. and Carracedo J. C. (2010) Evidence for distinct proportions of subducted oceanic crust and lithosphere in HIMU-type mantle beneath El Hierro and La Palma, Canary Islands. Geochim. Cosmochim. Acta 74, 6565-6589.

de Hoog J. C. M., Mason P. R. D. and van Bergen M. J. (2001) Sulfur and chalcophile elements in subduction zones: constraints from a laser ablation ICP-MS study of melt inclusions from Galunggung Volcano, Indonesia. Geochim. Cosmochim. Acta 65, 3147-3164.

Dixon J. E. and Stolper E. M. (1995) An experimental study of water and carbon dioxide solubilities in mid-ocean ridge basaltic liquids. 2. Applications to degassing. J. Petrol. 36, 1633-1646.

Dreher S. T., Macpherson C. G., Pearson D. G. and Davidson J. P. (2005) Re-Os isotope studies of Mindanao adakites: implications for sources of metals and melts. Geology 33, 957-960.

Eggler D. H. and Lorand J. P. (1993) Mantle sulfide geobarometry. Geochim. Cosmochim. Acta 57, 2213-2222.

Elliott T., Plank T., Zindler A., White W. and Bourdon B. (1997) Element transport from slab to volcanic front at the Mariana arc. J. Geophys. Res.-Solid Earth 102, 14991-15019.

Ewart A. and Bryan W. B. (1972) Petrography and geochemistry of igneous rocks from Eua, Tongan Islands. Geol. Soc. Am. Bull. 83, 3281 .

Ewart A. and Hawkesworth C. J. (1987) The pleistocene recent Tonga Kermadec arc lavas - interpretation of new isotopic and rare-earth data in terms of a depleted mantle source model. $J$. Petrol. 28, 495-530.

Fonseca R. O. C., Mallmann G., O’Neill H. S. C. and Campbell I. H. (2007) How chalcophile is rhenium? An experimental study of the solubility of Re in sulphide mattes. Earth Planet. Sci. Lett. 260, 537-548.

Gannoun A., Burton K. W., Thomas L. E., Parkinson I. J., van Calsteren P. and Schiano P. (2004) Osmium isotope heterogeneity in the constituent phases of mid- ocean ridge basalts. Science 303, 70-72.

Gannoun A., Burton K. W., Parkinson I. J., Alard O., Schiano P. and Thomas L. E. (2007) The scale and origin of the osmium isotope variations in mid-ocean ridge basalts. Earth Planet. Sci. Lett. 259, 541-556.

Garuti G., Zaccarini F. and Economou-Eliopoulos M. (1999) Paragenesis and composition of laurite from chromitites of Othrys (Greece): implications for Os- $\mathrm{Ru}$ fractionation in ophiolitic upper mantle of the Balkan peninsula. Miner. Depos. 34, 312-319. 
Gonzalez-Jimenez J. M., Proenza J. A., Gervilla F., Melgarejo J. C., Blanco-Moreno J. A., Ruiz-Sanchez R. and Griffin W. L. (2011) High-Cr and high-Al chromitites from the Sagua de Tanamo district, Mayari-Cristal ophiolitic massif (eastern Cuba): constraints on their origin from mineralogy and geochemistry of chromian spinel and platinum-group elements. Lithos 125, 101-121.

Hamlyn P. R., Keays R. R., Cameron W. E., Crawford A. J. and Waldron H. M. (1985) Precious metals in magnesian low-Ti lavas - implications for metallogenesis and sulfur saturation in primary magmas. Geochim. Cosmochim. Acta 49, 1797-1811.

Harvey J., Gannoun A., Burton K. W., Rogers N. W., Alard O. and Parkinson I. J. (2006) Ancient melt extraction from the oceanic upper mantle revealed by $\mathrm{Re}-\mathrm{Os}$ isotopes in abyssal peridotites from the mid-Atlantic ridge. Earth Planet. Sci. Lett. 244, 606-621.

Harvey J., Dale C. W., Gannoun A. and Burton K. W. (2011) Osmium mass balance in peridotite and the effects of mantlederived sulphides on basalt petrogenesis. Geochim. Cosmochim. Acta 75, 5574-5596.

Hauri E. H. and Hart S. R. (1997) Rhenium abundances and systematics in oceanic basalts. Chem. Geol. 139, 185-205.

Hawkesworth C. J., Gallagher K., Hergt J. M. and McDermott F. (1993) Mantle and slab contributions in arc magmas. Аnnu. Rev. Earth Planet. Sci. 21, 175-204.

Hawkins J. W. (1995) The geology of the Lau basin. In Backarc Basins: Tectonics and Magmatism (ed. B. Taylor). Plenum, New York, pp. 63-138.

Hermann J., Spandler C., Hack A. and Korsakov A. V. (2006) Aqueous fluids and hydrous melts in high-pressure and ultrahigh pressure rocks: implications for element transfer in subduction zones. Lithos 92, 399-417.

Ireland T. J., Walker R. J. and Garcia M. O. (2009) Highly siderophile element and Os-187 isotope systematics of Hawaiian picrites: implications for parental melt composition and source heterogeneity. Chem. Geol. 260, 112-128.

Jenner F. E., O’Neill H. S. C., Arculus R. J. and Mavrogenes J. A. (2010) The magnetite crisis in the evolution of arc-related magmas and the initial concentration of $\mathrm{Au}, \mathrm{Ag}$ and $\mathrm{Cu} . J$. Petrol. 51, 2445-2464.

Jugo P. J. (2009) Sulfur content at sulfide saturation in oxidized magmas. Geology 37, 415-418.

Jugo P. J., Wilke M. and Botcharnikov R. E. (2010) Sulfur K-edge XANES analysis of natural and synthetic basaltic glasses: implications for $\mathrm{S}$ speciation and $\mathrm{S}$ content as function of oxygen fugacity. Geochim. Cosmochim. Acta 74, 5926-5938.

Karrei, L.I., 2008. Elevated Pt, Pd and Au concentrations in High$\mathrm{Ca}$ Boninites from the Northern Tonga Arc: evidence for retention of monosulfide solid solution in the source, and the involvement of four independent components during petrogenesis, Dept of Geology. Masters thesis, University of Toronto, p. 69.

Keller N. S., Arculus R. J., Hermann J. and Richards S. (2008) Submarine back-arc lava with arc signature: Fonualei spreading center, northeast Lau Basin, Tonga. J. Geophys. Res.-Solid, Earth 113, B08s07.

Kepezhinskas P., Defant M. J. and Widom E. (2002) Abundance and distribution of PGE and $\mathrm{Au}$ in the island-arc mantle: implications for sub-arc metasomatism. Lithos 60, 113-128.

König S., Munker C., Schuth S., Luguet A., Hoffmann J. E. and Kuduon J. (2010) Boninites as windows into trace element mobility in subduction zones. Geochim. Cosmochim. Acta 74, 684-704.

Lassiter J. C. (2003) Rhenium volatility in sub-aerial lavas: constraints from subaerial and submarine portions of the HSDP-2 Mauna Kea drillcore. Earth Planet. Sci. Lett. 6766, 115.
Li C., Barnes S. J., Makovicky E., RoseHansen J. and Makovicky M. (1996) Partitioning of nickel, copper, iridium, rhenium, platinum, and palladium between monosulfide solid solution and sulfide liquid: effects of composition and temperature. Geochim. Cosmochim. Acta 60, 1231-1238.

Locmelis M., Pearson N. J., Barnes S. J. and Fiorentini M. L. (2011) Ruthenium in komatiitic chromite. Geochim. Cosmochim. Acta 75, 3645-3661.

Lorand J. P., Luguet A. and Alard O. (2008) Platinum-group elements: a new set of key tracers for the earth's interior. Elements 4, 247-252.

Lorand J. P., Alard O. and Luguet A. (2010) Platinum-group element micronuggets and refertilization process in Lherz orogenic peridotite (northeastern Pyrenees, France). Earth Planet. Sci. Lett. 289, 298-310.

Luguet A., Lorand J.-P., Alard O. and Cottin J.-Y. (2004) A multitechnique study of platinum group element systematic in some Ligurian ophiolitic peridotites, Italy. Chem. Geol. 208, 175-194.

Luguet A., Shirey S. B., Lorand J. P., Horan M. F. and Carlson R. W. (2007) Residual platinum-group minerals from highly depleted harzburgites of the Lherz massif (France) and their role in HSE fractionation of the mantle. Geochim. Cosmochim. Acta 71, 3082-3097.

Luguet A., Nowell G. M. and Pearson D. G. (2008a) ${ }^{184} \mathrm{Os} /{ }^{188} \mathrm{Os}$ and ${ }^{186} \mathrm{Os} /{ }^{188} \mathrm{Os}$ measurements by negative thermal ionisation mass spectrometry (N-TIMS): effects of interfering element and mass fractionation corrections on data accuracy and precision. Chem. Geol. 248, 342-362.

Luguet A., Pearson D. G., Nowell G. M., Dreher S. T., Coggon J. A., Spetsius Z. V. and Parman S. W. (2008b) Enriched Pt-ReOs isotope systematics in plume lavas explained by metasomatic sulfides. Science 319, 453-456.

Macpherson C. G. and Mattey D. P. (1998) Oxygen isotope variations in Lau Basin lavas. Chem. Geol. 144, 177-194.

Mathez E. A. (1976) Sulphur solubility and magmatic sulphides in submarine basalt glass. J. Geophys. Res. 81, 4249-4275.

Mavrogenes J. A. and O'Neill H. S. C. (1999) The relative effects of pressure, temperature and oxygen fugacity on the solubility of sulfide in mafic magmas. Geochim. Cosmochim. Acta 63, 11731180.

McInnes B. I. A., McBride J. S., Evans N. J., Lambert D. D. and Andrew A. S. (1999) Osmium isotope constraints on ore metal recycling in subduction zones. Science 286, 512-516.

Meisel T., Moser J., Fellner N., Wegscheider W. and Schoenberg R. (2001a) Simplified method for the determination of Ru, Pd, $\mathrm{Re}$, Os, Ir and Pt in chromitites and other geological materials by isotope dilution ICP-MS and acid digestion. Analyst 126, 322-328.

Meisel T., Walker R. J., Irving A. J. and Lorand J. P. (2001b) Osmium isotopic compositions of mantle xenoliths: a global perspective. Geochim. Cosmochim. Acta 65, 1311-1323.

Meisel T. and Moser J. (2004) Platinum-group element and rhenium concentrations in low abundance reference materials. Geostand. Geoanal. Res. 28, 233-250.

Meisel T., Dale C. W., Pearson D. G. and Sergeev D. S. (2009) Complete sample digestions for accurate isotope measurements? The Re-Os isotope system under scrutiny. Geochim. Cosmochim. Acta 73, A867.

Momme P., Tegner C., Brooks C. K. and Keays R. R. (2002) The behaviour of platinum-group elements in basalts from the East Greenland rifted margin. Contrib. Mineral. Petrol. 143, 133153.

Momme P., Oskarsson N. and Keays R. R. (2003) Platinum-group elements in the Icelandic rift system: melting processes and mantle sources beneath Iceland. Chem. Geol. 196, 209-234. 
Mungall J. E. (2002) Roasting the mantle: slab melting and the genesis of major $\mathrm{Au}$ and $\mathrm{Au}$-rich $\mathrm{Cu}$ deposits. Geology 30, 915918.

Mungall J. E., Andrews D. R. A., Cabri L. J., Sylvester P. J. and Tubrett M. (2005) Partitioning of $\mathrm{Cu}, \mathrm{Ni}, \mathrm{An}$, and platinumgroup elements between monosulfide solid solution and sulfide melt under controlled oxygen and sulfur fugacities. Geochim. Cosmochim. Acta 69, 4349-4360.

Mungall J. E., Karrei L. I., Arculus R. J. and Mavrogenes J. (2011) Controls on platinum-group element abundances in 110 samples of arc lavas from the Southwest Pacific. American Geophysical Union, Fall Meeting. Abstract \#V23B-2573.

Mungall J. E., Hanley J. J., Arndt N. T. and Debecdelievre A. (2006) Evidence from meimechites and other low-degree mantle melts for redox controls on mantle-crust fractionation of platinumgroup elements. Proc. Natl. Acad. Sci. USA 103, 12695-12700.

Naldrett A. J. (1969) A portion of the system Fe-S-O between 900 and 1080 degrees $\mathrm{C}$ and its application to sulfide ore magmas. Journal of Petrology 10, 171.

Park J.-W., Campbell I. H. and Eggins S. M. (2012) Enrichment of $\mathrm{Rh}, \mathrm{Ru}, \mathrm{Ir}$ and $\mathrm{Os}$ in $\mathrm{Cr}$ spinels from oxidized magmas: evidence from the Ambae volcano, Vanuatu. Geochim. Cosmochim. Acta 78, 28-50.

Parkinson I. J., Hawkesworth C. J. and Cohen A. S. (1998) Ancient mantle in a modern arc: osmium isotopes in Izu-Bonin-Mariana forearc peridotites. Science 281, 2011-2013.

Peach C. L., Mathez E. A. and Keays R. R. (1990) Sulfide melt silicate melt distribution coefficients for noble-metals and other chalcophile elements as deduced from MORB - implications for partial melting. Geochim. Cosmochim. Acta 54, 3379-3389.

Pearce J. A., Ernewein M., Bloomer S. H., Parson L. M., Murton B. J. and Johnson L. E. (1994) Geochemistry of Lau Basin volcanic rocks: influence of ridge segmentation and arc proximity. In Volcanism Associated with Extension at Consuming Plate Margins (ed. J. L. Smellie). London, Special Publication, Geological Society, pp. 53-75.

Pearce J. A. and Peate D. W. (1995) Tectonic implications of the composition of volcanic arc magmas. Annu. Rev. Earth Planet. Sci. 23, 251-285.

Pearson D. G. and Woodland S. J. (2000) Solvent extraction/anion exchange separation and determination of PGEs (Os, Ir, Pt, Pd, $\mathrm{Ru}$ ) and $\mathrm{Re}-\mathrm{Os}$ isotopes in geological samples by isotope dilution ICP-MS. Chem. Geol. 165, 87-107.

Pearson D. G., Irvine G. J., Ionov D. A., Boyd F. R. and Dreibus G. E. (2004) Re-Os isotope systematics and platinum group element fractionation during mantle melt extraction: a study of massif and xenolith peridotite suites. Chem. Geol. 208, 29-59.

Pearson D. G., Parman S. W. and Nowell G. M. (2007) A link between large mantle melting events and continent growth seen in osmium isotopes. Nature 449, 202-205.

Peregoedova A., Barnes S.-J. and Baker D. R. (2006) An experimental study of mass transfer of platinum-group elements, gold, nickel and copper in sulfur-dominated vapor at magmatic temperatures. Chem. Geol. 235, 59-75.

Plank T. and Langmuir C. H. (1993) Tracing trace-elements from sediment input to volcanic output at subduction zones. Nature 362, 739-743.

Plank T., Cooper L. B. and Manning C. E. (2009) Emerging geothermometers for estimating slab surface temperatures. Nat. Geosci. 2, 611-615.

Poreda R. J. and Craig H. (1992) He and Sr isotopes in the Lau basin mantle - depleted and primitive mantle components. Earth Planet. Sci. Lett. 113, 487-493.

Puchtel I. and Humayun M. (2000) Platinum group elements in kostomuksha komatiites and basalts: implications for oceanic crust recycling and core-mantle interaction. Geochim. Cosmochim. Acta 64, 4227-4242.

Puchtel I. S. and Humayun M. (2001) Platinum group element fractionation in a komatiitic basalt lava lake. Geochim. Cosmochim. Acta 65, 2979-2993.

Puchtel I. S., Brandon A. D. and Humayun M. (2004) Precise Pt$\mathrm{Re}-\mathrm{Os}$ isotope systematics of the mantle from 2.7-Ga komatiites. Earth Planet. Sci. Lett. 224, 157-174.

Regelous M., Turner S., Falloon T. J., Taylor P., Gamble J. and Green T. (2008) Mantle dynamics and mantle melting beneath Niuafo'ou Island and the northern Lau back-arc basin. Contrib. Mineral. Petrol. 156, 103-118.

Regelous M., Gamble J. A. and Turner S. P. (2010) Mechanism and timing of $\mathrm{Pb}$ transport from subducted oceanic crust and sediment to the mantle source of arc lavas. Chem. Geol. 273, 4654.

Rehkämper M., Halliday A. N., Fitton J. G., Lee D. C., Wieneke M. and Arndt N. T. (1999) Ir, Ru, Pt, and Pd in basalts and komatiites: new constraints for the geochemical behavior of the platinum-group elements in the mantle. Geochim. Cosmochim. Acta 63, 3915-3934.

Reisberg L., Zindler A., Marcantonio F., White W., Wyman D. and Weaver B. (1993) Os isotope systematics in ocean island basalts. Earth Planet. Sci. Lett. 120, 149-167.

Righter K., Chesley J. T., Calazza C. M., Gibson E. K. and Ruiz J. (2008) Re and Os concentrations in arc basalts: the roles of volatility and source region $\mathrm{fO}(2)$ variations. Geochim. Cosmochim. Acta 72, 926-947.

Rogers N. W., Thomas L. E., Macdonald R., Hawkesworth C. J. and Mokadem F. (2006) (238)U-(230)Th disequilibrium in recent basalts and dynamic melting beneath the Kenya rift. Chem. Geol. 234, 148-168.

Roy-Barman M. and Allegre C. J. (1994) ${ }^{187} \mathrm{Os}^{-186}{ }^{18 s}$ ratios of midocean ridge basalts and abyssal peridotites. Geochim. Cosmochim. Acta 58, 5043-5054.

Salters, V.J.M., Stracke, A., 2004. Composition of the depleted mantle. Geochem. Geophys. Geosyst. 5, Art. No.-Q05004.

Sen I. S., Bizimis M., Sen G. and Huang S. C. (2011) A radiogenic Os component in the oceanic lithosphere? Constraints from Hawaiian pyroxenite xenoliths. Geochim. Cosmochim. Acta 75, 4899-4916.

Shinotsuka K. and Suzuki K. (2007) Simultaneous determination of platinum group elements and rhenium in rock samples using isotope dilution inductively coupled plasma mass spectrometry after cation exchange separation followed by solvent extraction. Anal. Chim. Acta 603, 129, http://dx.doi.org/10.1016/j.aca.2007. 09.042 .

Shirey S. B. and Walker R. J. (1998) The Re-Os isotope system in cosmochemistry and high-temperature geochemistry. Annu. Rev. Earth Planet. Sci. 26, 423-500.

Snow J. E. and Reisberg L. (1995) Os isotopic systematics of the MORB mantle: results from altered abyssal peridotites. Earth Planet. Sci. Lett. 133, 411-421.

Sun W. D., Bennett V. C., Eggins S. M., Kamenetsky V. S. and Arculus R. J. (2003a) Enhanced mantle-to-crust rhenium transfer in undegassed arc magmas. Nature $\mathbf{4 2 2}$, 294-297.

Sun W., Bennett V. C., Eggins S. M., Arculus R. J. and Perfit M. R. (2003b) Rhenium systematics in submarine MORB and backarc basin glasses: laser ablation ICP-MS results. Chem. Geol. 196, 259-281.

Sun W. D., Arculus R. J., Kamenetsky V. S. and Binns R. A. (2004) Release of gold-bearing fluids in convergent margin magmas prompted by magnetite crystallization. Nature 431, 975-978. 
Suzuki K., Senda R. and Shimizu K. (2011) Osmium behavior in a subduction system elucidated from chromian spinel in Bonin island beach sands. Geology 39, 999-1002.

Turner S. and Hawkesworth C. (1997) Constraints on flux rates and mantle dynamics beneath island arcs from Tonga-Kermadec lava geochemistry. Nature 389, 568-573.

Walker R. J., Morgan J. W. and Horan M. F. (1995) ${ }^{187}$ Os enrichment in some plumes - evidence for core-mantle interaction. Science 269, 819-822.

Widom E. and Shirey S. B. (1996) Os isotope systematics in the Azores: implications for mantle plume sources. Earth Planet. Sci. Lett. 142, 451-465.

Widom E. (1997) Sources of ocean island basalts: a review of the osmium isotope evidence. Phys. A 244, 484-496.

Wood S. A., Mountain B. W. and Fenlon B. J. (1989) Thermodynamic constraints on the solubility of platinum and palladium in hydrothermal solutions - reassessment of hydroxide, bisulfide, and ammonia complexing. Econ. Geol. 84, 2020-2028.

Wood S. A., Mountain B. W. and Pan P. (1992) The aqueous geochemistry of platinum, palladium and gold - recent exper- imental constraints and a reevaluation of theoretical predictions. Can. Mineral. 30, 955-982.

Woodhead J. and Brauns M. (2004) Current limitations to the understanding of $\mathrm{Re}-\mathrm{Os}$ behaviour in subduction systems, with an example from New Britain. Earth Planet. Sci. Lett. 221, 309323.

Woodhead J. D., Hergt J. M., Davidson J. P. and Eggins S. M. (2001) Hafnium isotope evidence for 'conservative' element mobility during subduction zone processes. Earth Planet. Sci. Lett. 192, 331-346.

Woodland S. J., Pearson D. G. and Thirlwall M. F. (2002) A platinum group element and $\mathrm{Re}-\mathrm{Os}$ isotope investigation of siderophile element recycling in subduction zones: comparison of Grenada, Lesser Antilles arc, and the Izu-Bonin arc. $J$. Petrol. 43, 171-198.

Zellmer K. E. and Taylor B. (2001) A three-plate kinematic model for Lau Basin opening. Geochem. Geophys. Geosyst. 2.

Associate editor: Richard J. Walker 